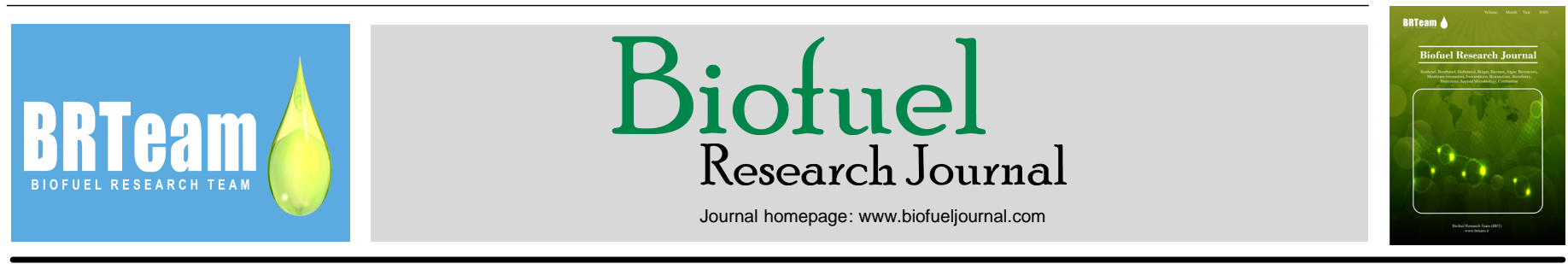

Original Research Paper

\title{
Attributional and consequential environmental assessment of using waste cooking oil- and poultry fat-based biodiesel blends in urban buses: a real-world operation condition study
} \author{
Askari $^{5}$, Ali Zenouzi ${ }^{6}$, Mahan Ghorbani ${ }^{7}$ \\ ${ }^{I}$ Department of Biosystems Engineering, Faculty of Agriculture, University of Tabriz, Tabriz, Iran. \\ ${ }^{2}$ Biofuel Research Team (BRTeam), Karaj, Iran. \\ ${ }^{3}$ Microbial Biotechnology Department, Agricultural Biotechnology Research Institute of Iran (ABRII), AREEO, Karaj, Iran. \\ ${ }^{4}$ Applied Biotechnology Research Center, Baqiyatallah University of Medical Sciences, Tehran, Iran. \\ ${ }^{5}$ Tehran Bus Co., Tehran, Iran. \\ ${ }^{6}$ Iranian Research Organization for Science and Technology (IROST), Tehran, Iran. \\ ${ }^{7}$ Department of Forestry, Faculty of Natural resources, University of Tehran, Tehran, Iran.
}

Mohammad Ali Rajaeifar ${ }^{1, *}$, Meisam Tabatabaei ${ }^{2,3, *}$, Reza Abdi $^{1, *}$, Ali Mohammad Latifi ${ }^{4}$, Fatemeh Saberi $^{4}$, Mohammad

\section{HIGHLIGHTS}

$>$ Emissions attributed to WCO and PF biodiesel blends in urban buses were measured in idle operation mode.

Attributional and consequential environmental impacts of the investigated fuels were evaluated by a well to wheel LCA

$>$ Compared with B5-PF fuel blend, B5-WCO fuel blend was found eco-friendly diesel alternative for the Iranian urban transportation sector.

\section{GRAPHICAL ABSTRACT}

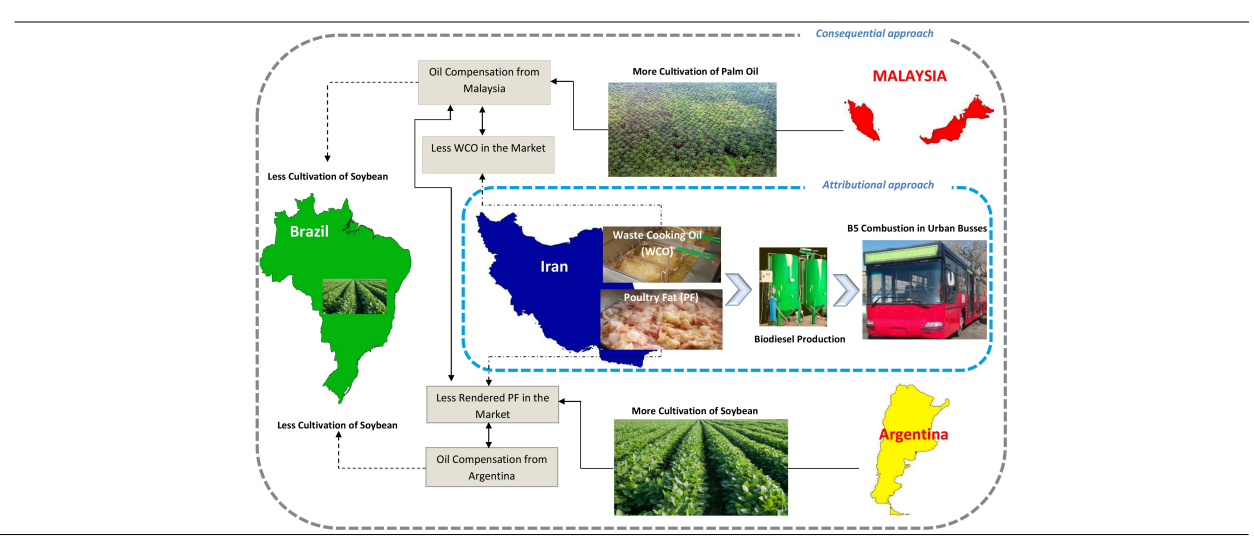

\section{ARTICLE INFO}

\section{Article history:}

Received 15 June 2017

Received in revised form 23 July 2017

Accepted 28 July 2017

Available online 1 September 2017

\section{Keywords:}

Urban public transportation sector

Bus

Idle operation

Biodiesel

Attributional LCA

Consequential LCA

\begin{abstract}
Urban public transportation sector in general is heavily dependent on fossil - oriented fuels, e.g., diesel. Given the fact that a major proportion of urban pollution and the consequent threats towards public health are attributed to this sector, serious efforts at both technical and political levels have been being made to introduce less-polluting fueling regimes, e.g., partial replacement of diesel with biodiesel. In line with that, the present study was aimed at evaluating the emissions attributed to $5 \%$ blends of waste cooking oil (WCO) and poultry fat (PF) biodiesel fuels (i.e., B5-WCO and B5-PF fuel blends) when used in urban buses during idle operation mode. Moreover, the attributional and consequential environmental impacts of using these fuel blends were also investigated through a well to wheel life cycle assessment (LCA) by considering the real-world condition combustion data using ten urban buses. The findings of the ALCA revealed that the application of 1 L B5-WCO fuel blend could potentially reduce the environmental burdens in human health, ecosystem quality, and resources damage categories compared with using the B5-PF fuel blend. The situation was opposite for climate change damage category in which using 1 L B5-PF fuel blend had a lower impact on the environment. Overall, the environmental hotspots in the B5-WCO and B5-PF life cycles were identified as the combustion stage as well as the diesel production and transportation. From the consequential perspective, using 1 L B5WCO fuel blend could potentially decrease the environmental burdens in human health, ecosystem quality, and resources damage categories. While, the situation was different for climate change damage category where using $1 \mathrm{~L}$ B5-PF fuel blend could have a lower impact on the environment. In conclusion, using B5-WCO fuel blend as an alternative for diesel could be an environmentally-friendly decision for the Iranian urban transportation sector at the policy level as long as the marginal suppliers of oil would be the same as the countries considered herein, i.e., Malaysia and Argentina.
\end{abstract}

(c) 2017 BRTeam. All rights reserved.

* Corresponding author at: Tel.: +989358555429, E-mail address: Mohamad_rajaei@ut.ac.ir (M.A.R.); Tel.:+98-9132865342, E-mail address: meisam_tab@yahoo.com \& meisam_tabatabaei@abrii.ac.ir (M.T.); Tel.: +989144063892,E-mail address: r.abdi@tabrizu.ac.ir (R.A.) 


\section{Introduction}

It is obvious that the current modern world heavily relies on fossil resources in order meet its increasing energy demands. Statistically, more than $80 \%$ of the current world's energy consumption is fossil-based (Aghbashlo et al., 2017), and projections show that the world's total energy consumption will reach a staggering 815 quadrillion British thermal unit (BTU) in the year 2040 (i.e., $48 \%$ increase compared with that of the year 2012), out of which $78 \%$ will be of fossil fuels origin (Ashokkumar et al., 2017). Major concerns associated with such high share of fossil fuels in the global energy basket is their negative impacts on human and environmental health through the widespread utilization of these fuels and the resultant greenhouse gases (GHGs), particulate, and many other respiratory emissions (Cohen and Pope, 1995; Caldeira and Wickett, 2003; Demirbas, 2007; Covert et al., 2016; Röllin, 2017). Therefore, most energy scenarios have been based on the development and expansion of nuclear and renewable energy carriers (Carneiro et al., 2017).

The negative health impacts of fossil fuels combustion are more intense in cities where more than half of the world's population resides (Hoornweg and Bhada-Tata, 2012). Different sectors including transportation, business and household, as well as primary electricity generation are the main emitting sectors located inside or in the vicinity of major cities. Unfortunately, these sectors are predominantly dependent on fossil fuel resources and are responsible for high level of anthropogenic air pollution and GHG emissions in metropolitans. For instance, approximately $95 \%$ of the energy demands in the transportation sector is is met by fossil-oriented fuels (Rajaeifar et al., 2016). Therefore, the application of renewable energies such as biofuels is regarded as a key mitigation strategy for these sectors.

Among different renewable energies, liquid biofuels such as biodiesel are considered as promising alternative to liquid fossil fuels in-use such as petroleum diesel. Accordingly, numerous studies have been carried out to investigate engine performance and tailpipe emission characteristics of biodiesel (Ashraful et al., 2014; Attia and Hassaneen, 2016; Thangaraja et al., 2016; Al-lwayzy and Yusaf, 2017). Most of the reports indicate that biodiesel generally reduces PM, CO, and unburned hydrocarbons (UHC) emissions while decreases carbon deposits and wears of the key parts of engines as well. On the other hand, although some reports claim reductions in engine power at high biodiesel inclusion rates (Mohammadi et al., 2012) no significant variations in this criterion were observed when low biodiesel inclusion rates, e.g., between 2 to 5\%, were investigated (Xue et al., 2011).

It should also be highlighted that the majority of the above-mentioned studies were conducted under steady-state conditions (laboratory chassis dynamometer tests) and only very few reports are available in which real-world conditions were considered. Obviously scrutinizing the impacts of biodiesel under real-world conditions (i.e., using vehicles serving under routine working conditions and exact driving cycle) would lead to be more realistic results compared with results obtained under theoretical cycles or alternatively driving cycles based on average data collected on drivers` behavior and vehicle $v s$. road conditions. The latter is generally used in steady-state combustion tests. Table 1 tabulated the findings of a number of research studies conducted under realworld operation conditions in different parts of the world. However, these studies suffer from one or more of the following weakness, i.e., 1) uncertainty in the statistical analysis implemented, 2) uncertainty in the driving cycle used, and 3) using out of standard biodiesel.

It should also be noted that either under steady-state or real-world conditions, combustion is not the only stage which should be considered in analyzing the pros and cons of biodiesel implementation in transportation fleets. In better words, a sustainable use of biodiesel should be inspected through all the stages involved, i.e., from raw material extraction to biodiesel consumption. In such context, life cycle assessment (LCA) could be used effectively in order to assess the environmental impacts of a dedicated biofuel throughout its life cycle on a cradle to grave basis. This technique has been broadly implemented to support the sustainability criteria of various renewable energy systems (Khoshnevisan et al., 2016), i.e., their energy, environmental and economic aspects. A summary of LCA studies on biodiesel production/consumption and their technical features are presented in Table 2. It should be noted that the impacts of biodiesel on various impact categories could be different depending on feedstock used for biodiesel, fuel properties (e.g., viscosity, cetane number, etc.), engine characteristics, and operating conditions (Rajaeifar et al., 2017). Accordingly, most of the reviewed studies, tabulated in Table 2, suffer from one or more of the following weaknesses, i.e.,
1) incomplete impact coverage, 2) overlooking one or some of the stages involved in the life cycle (well to tank analysis), and 3) using steady-state or database combustion data. Moreover, most existing LCA studies are based on the attributional approach, but the tendency is for studies to increasingly employ the consequential approach (Dalgaard et al., 2008).

Therefore, the present study was set in order to address the shortcomings found in real-world operation studies on biodiesel (Table 1) and those present in LCA of biodiesel (Table 2). More specifically, the emissions attributed to waste cooking oil (WCO) and poultry fat (PF) biodiesel blends when used in urban buses were measured in idle operation mode using an accurate statistical analysis. It should be mentioned that measuring emissions in idle operation mode is very important since idle engine operation of vehicles, usually taking place during heavy traffics or at stations, is associated with significant negative health and environmental impacts (Nerella, 2010). The attributional and consequential environmental impacts of the investigated biodiesel fuels were also evaluated through a well to wheel LCA by considering the real-world condition combustion data using ten urban buses.

\section{Materials and Methods}

\subsection{Feedstock preparation and biodiesel production}

The first stage of the present study included collection, transportation, and preparation of WCO and PF as the main feedstocks for biodiesel production. More specifically, WCO was collected from restaurants while rendered PF was collected from poultry rendering plants. The specific location of the restaurants, the rendering plants, and the biodiesel production center as well as the transportation method are explained in the LCA inventory data.

The presence of water and free fatty acids (FFAs) in the feedstock could significantly affect the transesterification of glycerides with alcohols, decreasing reaction efficiency especially when alkali catalysts are used (Ma and Hanna, 1999; Van Gerpen, 2005). Therefore, the second stage included the pretreatment of the feedstocks to meet the standards required for biodiesel production. Accordingly, the water content of the WCO and the PF were removed by heating and sedimentation method. To address the FFA content problem, following the determination of FFA content, an extra amount of alkali catalyst was added in the transesterification reaction as previously suggested by Clements and Gerpen (2004). Briefly, the total FFA content of the oils were determined by a titrimetric method as described in the ISO 660 (ISO:660, 2009) and the amount of the additional alkali catalyst used was calculated using the equations proposed by Clements and Gerpen (2004). Finally, the prepared oils were sent to a conventional reactor (a batch reactor, $3000 \mathrm{~L}$ capacity with an automatic stirring and a temperature control, equipped with a bubble washing system) in which it reacted with methanol (as alcohol) in the presence of potassium hydroxide $(\mathrm{KOH})$ as catalyst. It is also worth quoting that the properties of the produced biodiesel were finally examined based on procedures set forth by the ASTM D 6751.

\subsection{Test vehicles, facilities, and experimental procedure}

The third stage of the present study was to assess the tailpipe idle emissions of the WCO- and PF-based biodiesel blends in urban buses. In order to reach this goal, 10 urban buses from the public transportation system of Tehran metropolitan was selected as case study. Tehran metropolitan, the capital of Iran, is the most populated area in the country with more than 12 million inhabitants as announced in the year 2017. The region covers an area of $730 \mathrm{~km}^{2}$ encompassing 22 districts each governed by a semi-autonomous municipality. The public transport infrastructure in Tehran consists of a road network throughout the city and an underground metro-rail network. The road public transportation network is mainly handled by Tehran Urban Bus Company managing 310 lines covering more than $3000 \mathrm{~km}$ in length as well as Tehran Taxi Company managing 450 lines covering more than $4291 \mathrm{~km}$ in length. The underground metro-rail network is also managed and facilitated by Tehran Urban \& Suburban Railway Operation Company covering 6 main lines and more than $189 \mathrm{~km}$ in length (TehranMunicipality, 2017). 
Table 1.

Summary of studies conducted in real-world operation conditions throughout the world.

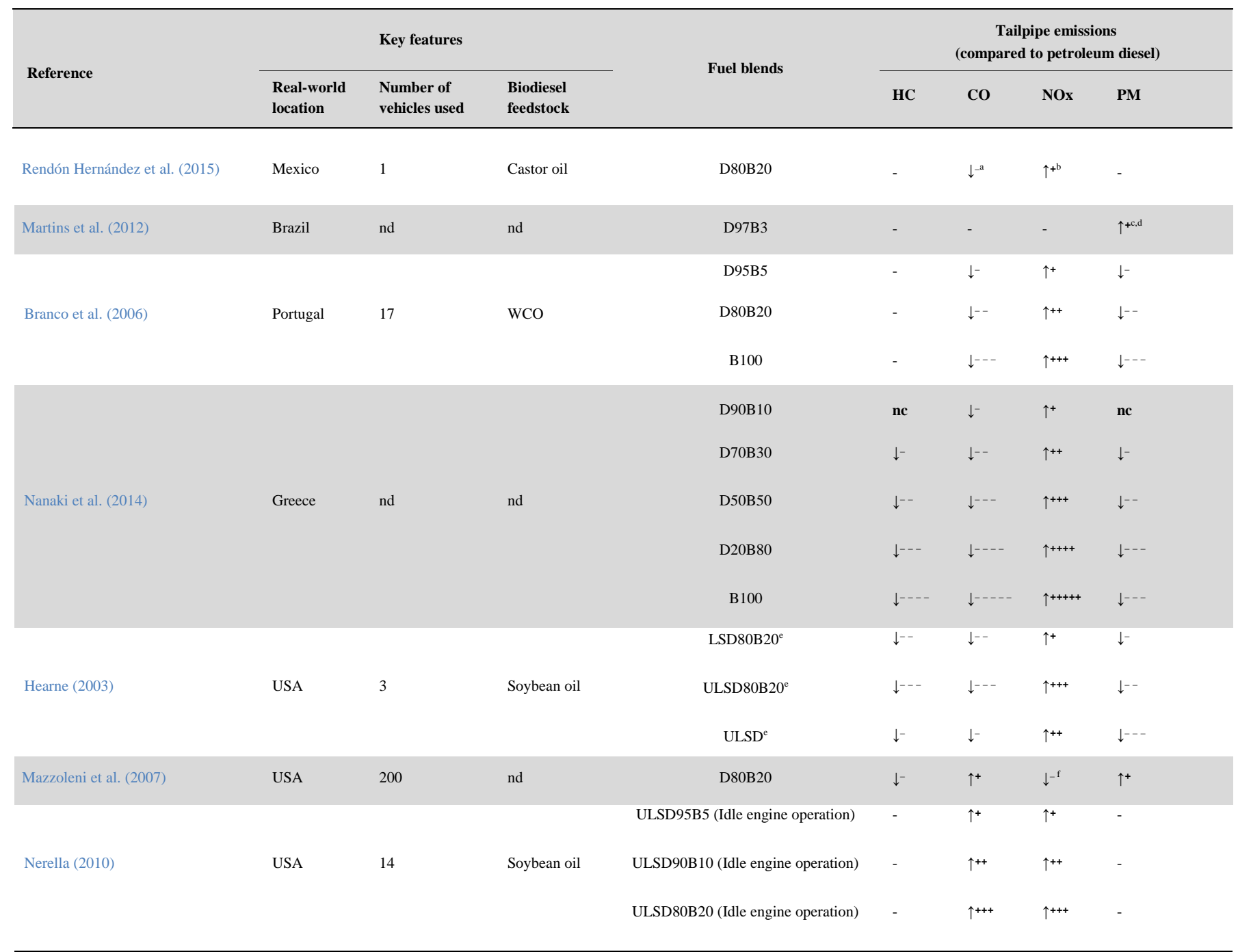

DXBY $=$ X\% diesel in combination with Y\% biodiesel, $\mathbf{L S D}=$ Low sulphur diesel, $\mathbf{U L S D}=$ Ultra low sulphur diesel, $\mathbf{n d}=$ not determined, $\mathbf{n c}=$ no change in comparison with the reference fuel.

The symbols $\uparrow / \downarrow$ and $+/$-represent the trend and the intensity of variations observed in each study, respectively, and cannot be used as a means of comparison among different studies.
$\mathrm{a}=$ in both highway and urban areas driving conditions, $\mathrm{b}=$ NOx emissions decreased in the highway driving condition, $\mathrm{c}=$ fine and ultrafine particles, $\mathrm{d}=\mathrm{PAH}$ emissions decreased, $\mathrm{e}=$ reference fuel was low $\mathrm{a}=$ in both highway and urban areas driving conditions
sulfur diesel, $\mathrm{f}=$ Only NO emissions was reported.

In order to perform the experiment at this stage, the urban buses selected were among the most commonly used type of bus engines in the Tehran public transportation fleet, i.e., Renault-Shahab Khodro buses. Table 3 shows the engine specifications of the buses under investigation in the present study.

Idle-emission testing was conducted on-site at the location of the Station 9 of the Tehran Bus Company throughout February 2016. Since the measurements were focused on hot-start emissions; therefore, the vehicles were warmed up for $15 \mathrm{~min}$ before the emissions measurement were carried out. Subsequently, the tailpipe emissions were measured during low-speed and high speed of the engine under idle condition. The fuels tested were B5-WCO (5\% WCO-biodiesel blended with 95\% fossil diesel), B5-PF (5\% PF-biodiesel blended with $95 \%$ fossil diesel) and neat fossil diesel. In fact, in order to improve the reliability of the results, a control treatment was also included (i.e., petroleum diesel No.2) and its resultant tailpipe emissions were assessed

Emissions measurements were performed using an AVL emission tester series 4000-Dicom 4000 (Austria), capable of measuring $\mathrm{CO}, \mathrm{CO}_{2}, \mathrm{NO}_{\mathrm{x}}$, $\mathrm{HC}, \mathrm{O}_{2}$ gases as well as $\lambda$ (air-to-fuel equivalence ratio) and k-value (Absorption) indices. The analyzer set-up was connected to the exhaust pipe as shown in Figure 1.

In order to reduce the uncertainty in the statistical analysis, a completely randomized design (CRD) was implemented and the impacts of the abovementioned biodiesel blends (as main treatments) on the tailpipe emissions under idle condition using 10 buses (replications) were investigated. The impact of the above mentioned fuels were finally analyzed and compared using a statistical analysis software, i.e., SPSS 19 spreadsheets. 
Table 2.

Summary of LCA studies conducted on biodiesel production/consumption throughout the world.

\begin{tabular}{|c|c|c|c|c|c|c|}
\hline \multirow{2}{*}{ Reference } & \multicolumn{2}{|c|}{ Key features } & \multicolumn{3}{|c|}{ Studied impacts } & \multirow{2}{*}{ Results } \\
\hline & $\begin{array}{l}\text { Geographical } \\
\text { scale }\end{array}$ & $\begin{array}{l}\text { Biodiesel } \\
\text { feedstock }\end{array}$ & Toxic $^{\mathrm{a}}$ & Non-toxic ${ }^{b}$ & Resources $^{c}$ & \\
\hline
\end{tabular}

\begin{tabular}{|c|c|c|c|c|c|c|}
\hline Escobar et al. (2014) & Spain & $\begin{array}{l}\text { WCO vs. Soybean } \\
\text { oil }^{\text {d }}\end{array}$ & PC & $\mathrm{CC}$ & No & $\begin{array}{l}\text {-WCO biodiesel shows better impact in all the studied impact } \\
\text { categories compared with imported soybean-based biodiesel } \\
\text { (except in global warming). }\end{array}$ \\
\hline
\end{tabular}

\begin{tabular}{|c|c|c|c|c|c|c|}
\hline Fernández-Tirado et al. (2016) & Spain & $\begin{array}{l}\text { Rapeseed oil vs. } \\
\text { Soybean oil }^{\mathrm{d}}\end{array}$ & PC & $\mathrm{CC}$ & PC & $\begin{array}{l}\text {-Biodiesel produced with imported soybean oil had fewer } \\
\text { environmental impacts than biodiesel produced with Spanish } \\
\text { rapeseed oil. }\end{array}$ \\
\hline
\end{tabular}

\begin{tabular}{|c|c|c|c|c|c|c|}
\hline Aoun et al. (2016) & France & Rapeseed oil ${ }^{\mathrm{d}}$ & No & $\mathrm{CC}$ & No & $\begin{array}{l}\text {-Compared with petroleum diesel, biodiesel production from } \\
\text { rapeseed shows better impact in global warming while increasing } \\
\text { eutrophication, and photochemical oxidation. }\end{array}$ \\
\hline
\end{tabular}

\begin{tabular}{|c|c|c|c|c|c|c|}
\hline Moecke et al. (2016) & Brazil & $\mathrm{WCO}^{\mathrm{d}}$ & No & $\mathrm{PC}$ & No & $\begin{array}{l}\text {-WCO biodiesel reduces global warming impact compared with } \\
\text { petroleum diesel. }\end{array}$ \\
\hline
\end{tabular}

\begin{tabular}{|c|c|c|c|c|c|c|}
\hline Fernandez et al. (2017) & Brazil & $\begin{array}{l}\text { WCO vs. Soybean } \\
\text { oil }^{d}\end{array}$ & $\mathrm{CC}$ & $\mathrm{CC}$ & No & $\begin{array}{l}\text {-Compared with conventional transesterification using alkali } \\
\text { catalysts, biodiesel production from WCO or soybean oil could } \\
\text { have lower impacts if enzyme catalysts are employed in the } \\
\text { transesterification reaction. }\end{array}$ \\
\hline
\end{tabular}

\begin{tabular}{|c|c|c|c|c|c|c|}
\hline Dufour and Iribarren (2012) & Spain & $\begin{array}{l}\text { Waste vegetable } \\
\text { oils, beef tallow, } \\
\text { poultry fat sewage } \\
\text { sludges }^{\text {d }}\end{array}$ & $\mathrm{PC}$ & $\mathrm{CC}$ & $\mathrm{CC}$ & $\begin{array}{l}\text {-Compared with petroleum diesel, biodiesel production reduces } \\
\text { global warming, ozone layer depletion and cumulative non- } \\
\text { renewable energy demand while increases acidification and } \\
\text { eutrophication. }\end{array}$ \\
\hline Yee et al. (2009) & Malaysia & Palm oil $^{\mathrm{d}}$ & No & $\mathrm{PC}$ & No & $\begin{array}{l}\text {-Palm-based biodiesel reduces global warming impact compared } \\
\text { with petroleum diesel. }\end{array}$ \\
\hline Kumar et al. (2012) & India & Jatropha oil ${ }^{\mathrm{d}}$ & No & $\mathrm{PC}$ & No & $\begin{array}{l}\text {-Jatropha-based biodiesel reduces global warming impact } \\
\text { compared with petroleum diesel. }\end{array}$ \\
\hline
\end{tabular}

$\begin{array}{llll}\text { Altamirano et al. (2016) } \quad \text { Brazil } \quad \text { Soybean oil } & \text { PC } & \text { PC } & \text { No } \quad \begin{array}{l}\text {-Compared with petroleum diesel, soybean-based biodiesel shows } \\ \text { a better impact on global warming while increases acidification, } \\ \text { eutrophication and human Toxicity Potential. }\end{array}\end{array}$

\begin{tabular}{|c|c|c|c|c|c|c|}
\hline Pleanjai et al. (2009) & Thailand & $\mathrm{WCO}^{\mathrm{c}}$ & No & $\mathrm{PC}$ & No & $\begin{array}{l}\text {-WCO biodiesel reduces global warming impact compared with } \\
\text { petroleum diesel. }\end{array}$ \\
\hline
\end{tabular}

Gnansounou and Raman

Gnansounou and Raman
(2016) $\quad$ India
-Less $\mathrm{CO}_{2}$ emissions and land use for algae-based biodiesel, protein and succinic acid production system compared to that of only biodiesel and protein production system from algae considered. The impact reduction was even more when compared with conventional diesel, soy protein and fossil based succinic acid system.

\begin{tabular}{|c|c|c|c|c|c|c|}
\hline Jørgensen et al. (2012) & Denmark & Poultry fat oil ${ }^{\mathrm{e}}$ & No & PC & No & $\begin{array}{l}\text {-Poultry fat-based biodiesel reduces global warming impact } \\
\text { compared with petroleum diesel. }\end{array}$ \\
\hline Sheehan et al. (1998) & USA & Soybean oil ${ }^{\mathrm{e}}$ & $\mathrm{PC}$ & PC & $\mathrm{CC}$ & $\begin{array}{l}\text {-Soybean-based biodiesel could substantially improve some air } \\
\text { pollutants (except NOx emissions), reduce global warming, } \\
\text { wastewater flows and oil consumption while it has potential to } \\
\text { increase water consumption, some fossil (natural gas and coal) } \\
\text { and mineral resources. }\end{array}$ \\
\hline Xue et al. (2012) & USA & Soybean oil ${ }^{\mathrm{c}}$ & $\mathrm{PC}$ & PC & No & $\begin{array}{l}\text {-Compared with ultra-low sulfur diesel, soybean-based biodiesel } \\
\text { reduces global warming, non-carcinogens, and ecotoxicity } \\
\text { impacts, while increases carcinogens, respiratory, eutrophication, } \\
\text { and smog impacts. }\end{array}$ \\
\hline
\end{tabular}

Nanaki and Koroneos (2012) $\quad$ Greece $\quad$ Rapeseed oil ${ }^{\mathrm{e}} \quad$ PC $\quad$ PC PC

-Compared with petroleum diesel, rapeseed-based biodiesel reduces global warming, respiratory organics, carcinogens, acidification and eutrophication, while increases respiratory inorganics and ecotoxicity.

Please cite this article as: Rajaeifar M.A., Tabatabaei M., Abdi R., Latifi A.M., Saberi F., Askari M., Zenouzi A., Ghorbani M. Attributional and consequential environmental assessment of using waste cooking oil- and poultry fat-based biodiesel blends in urban buses: a real-world operation condition study. Biofuel Research Journal 15 (2017) 638-653. DOI: 10.18331/BRJ2017.4.3.3 
Table 2.

(Continiued).

\begin{tabular}{|c|c|c|c|c|c|c|}
\hline \multirow{2}{*}{ Reference } & \multicolumn{2}{|c|}{ Key features } & \multicolumn{3}{|c|}{ Studied impacts } & \multirow{2}{*}{ Results } \\
\hline & $\begin{array}{l}\text { Geographical } \\
\text { scale }\end{array}$ & $\begin{array}{l}\text { Biodiesel } \\
\text { feedstock }\end{array}$ & Toxic $^{\text {a }}$ & Non-toxic ${ }^{\mathrm{b}}$ & Resources $^{\mathrm{c}}$ & \\
\hline Montrimaitè et al. (2010) & Lithuania & $\mathrm{WCO}^{\mathrm{c}}$ & No & $\mathrm{PC}$ & No & $\begin{array}{l}\text { - WCO biodiesel reduces global warming impact compared with } \\
\text { petroleum diesel. }\end{array}$ \\
\hline Tu et al. (2015) & USA & $\mathrm{WCO}^{\mathrm{e}}$ & No & $\mathrm{PC}$ & No & $\begin{array}{l}\text {-WCO biodiesel reduces global warming impact compared with } \\
\text { petroleum diesel. }\end{array}$ \\
\hline Lardon et al. (2009) & nd & Microalgae $^{e}$ & $\mathrm{PC}$ & $\mathrm{PC}$ & No & $\begin{array}{l}\text {-Compared with petroleum diesel, biodiesel from Microalgae } \\
\text { showed a lower impact on abiotic depletion, ozone layer depletion } \\
\text { and global warming. }\end{array}$ \\
\hline
\end{tabular}

$a=$ Toxic impact categories include: ecotoxicity, and human toxicity; $b=$ Non-toxic impact categories include : acidification, eutrophication, gobal warming (GW), ozone Layer depletion, tropospheric ozone formation; $\mathrm{c}=$ Resources include mineral and fossils depletion; $\mathrm{d}=$ system boundary from cradle to gate (consumption phase i.e., combustion of the fuels were omitted) and there is no explanation about the fuel delivery method, $\mathrm{e}=$ system boundary from well to wheel. (CC: complete coverage; PC: partial coverage (some impact categories missing); No: no coverage, nd= not determined.

Table 3.

Engine specefications of the buses under investigation in the present study.

\begin{tabular}{ll}
\hline Engine Model & Renault MIDR 062045 C4 \\
\hline Type & 4 Stroke, Water cooled, Turbcharged, Inter cooled \\
\hline Engine Volume & $10 \mathrm{Lit}$ \\
Displacement & $1670 \mathrm{~cm}^{3}$ \\
No. Cylinders & 6 in Line \\
Compression Ratio & 17.1 \\
Max Output & $188 \mathrm{~kW}$ at $2100 \mathrm{rpm}$ \\
\hline Max Torque & $1000 \mathrm{Nm}$ at $1400 \mathrm{rpm}$ \\
\hline Low speed of engine (idle or 0\% load) & $550 \mathrm{rpm}$ \\
\hline Maximum speed of engine & $2100 \mathrm{rpm}$ \\
\hline
\end{tabular}
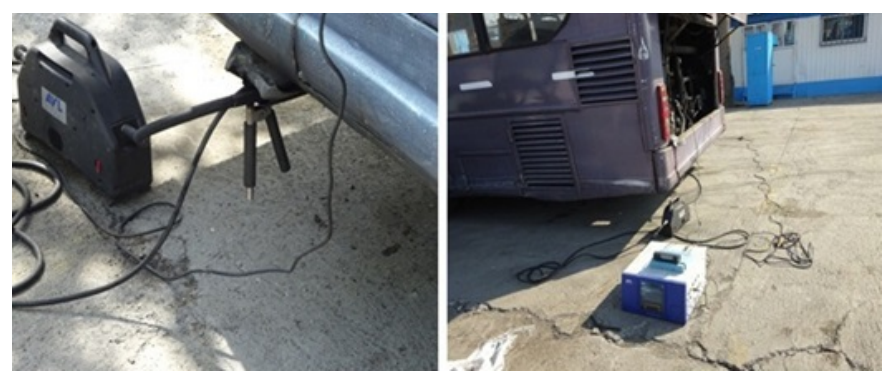

Fig.1. Analyzer set-up and the tailpipe emission testing operation.

\subsection{Life cycle assessment (LCA)}

The final stage of the present study included performing an LCA according to the ISO standards on LCA (ISO, 2006a, 2006b). The methodological aspects are explained in the following sub-sections.

\subsubsection{Goal and scope definition}

As mentioned earlier, the goal of the present LCA study was to evaluate the environmental impacts of using WCO- and PF-based biodiesel in urban buses.
In order to reach this goal, two fundamentally-different approaches were employed, i.e., attributional and consequential LCA. Accordingly, the scope of the attributional life cycle assessment (ALCA) consisted of the major stages involved in the life cycle of any second-generation biodiesel fuels, including feedstock collection, biodiesel production and combustion of the fuels. While in the consequential life cycle assessment (CLCA), the system boundaries were expanded so that the agricultural production of the marginal products as well as the oil mill stage and transportation of the marginal products were also considered in the calculations. In order to avoid any confusion, the system boundaries are comprehensively explained in the following. It is also worth quoting that the functional unit (FU) of the present LCA study was considered as the combustion of 1 L B5 from the $\mathrm{WCO}$ or PF in the urban buses under investigation.

\subsubsection{Attributional life cycle assessment}

In an ALCA study, the environmental burden of a product/service is assessed assuming a status quo situation describing the environmentally relevant flows to and from a life cycle and its subsystems (Finnveden et al., 2009; Wiloso and Heijungs, 2013). Although this method could potentially help to find the main hot spots in a given life cycle chain as well as the share of certain emissions, or flows to an impact category, it could not help with policy decisions since its purpose is not to support changes in future (including demands in global/local market, technology, and economy) Moreover, the application of the ALCA approach in bioenergy chains could also help to find the effect of changing feedstocks, changing production processes, or improving efficiency on the main environmental emissions from bioenergy systems (Wiloso and Heijungs, 2013). Figure 2 shows the system boundary of the ALCA performed in this study. Accordingly, two scenarios were defined as follows:

$$
\begin{array}{ll}
\text { A. } & \text { Combustion of B5-PF (attributional modeling) } \\
B . & \text { Combustion of B5-WCO (attributional modeling) }
\end{array}
$$

\subsubsection{Consequential life cycle assessment}

In a CLCA method, the attempt is to investigate the degree of changes in the environmental flows (resource use and emissions) in response to possible decisions (Finnveden et al., 2009). This question is mainly answered by defining futuristic scenarios (Khoshnevisan et al., 2017) in which the main attempt is to, 1) model the technology (or processes) actually affected by a change in demand (which is called the marginal technology), and 2) avoid co-product allocation through system expansion (Dalgaard et al., 2008). Nevertheless, in the ALCA approach, average technology (instead of marginal) is used and co-product allocation is often 


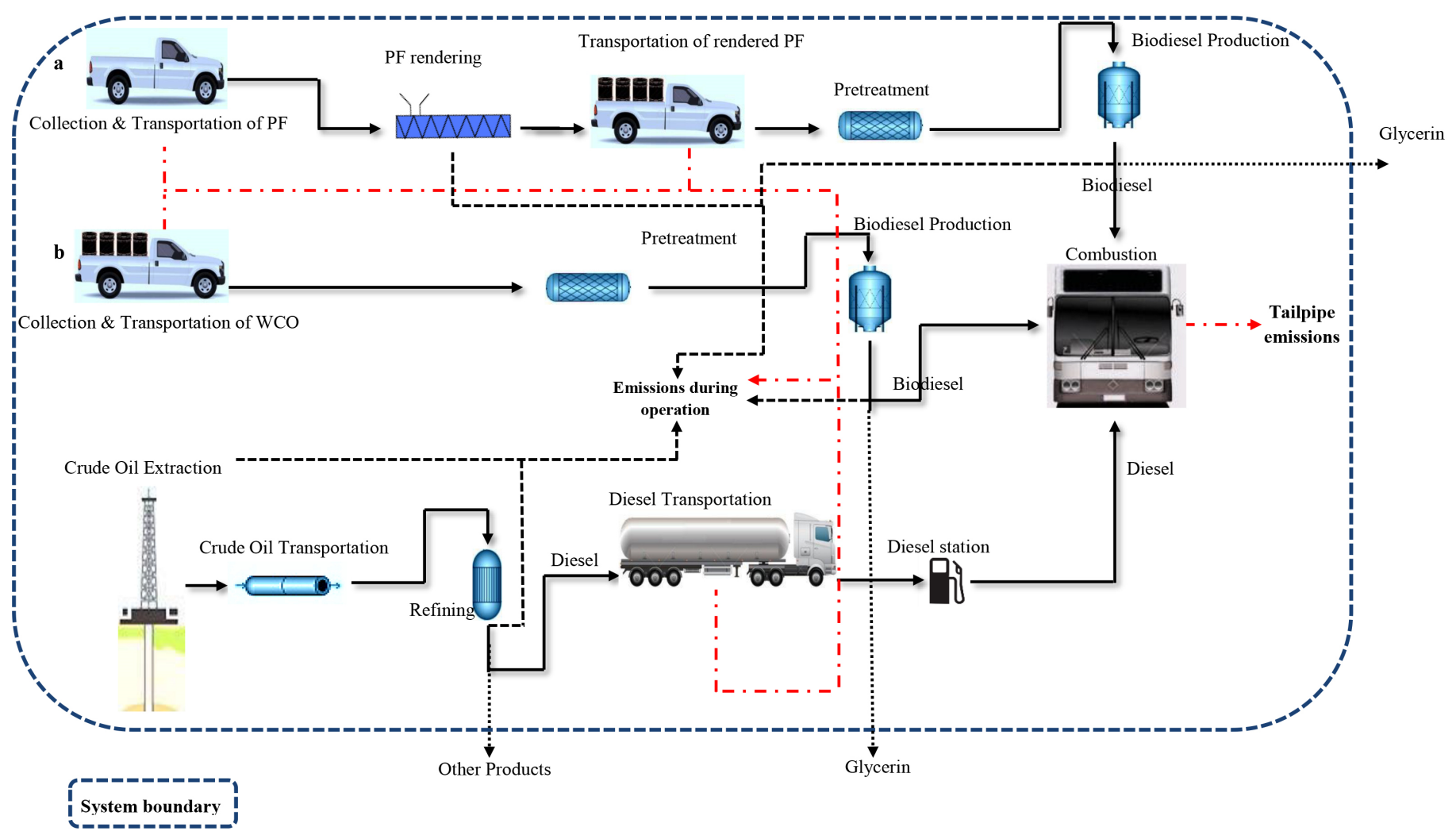

Fig.2. System boundary of the ALCA performed in this study.

performed (based on mass, energy or economic value of the product and coproducts) (Weidema, 2003).

A consequential look at the scenarios A and B highlights the question that what most probable changes could be expected in response to the use of PF or WCO for biodiesel production. In order to address this question, the first step was to find out the other applications (rather than the use for biodiesel production) of $\mathrm{PF}$ and WCO in the local market. Accordingly, it was determined that PF was often used by poultry feed production industry in Iran while WCO was either disposed of or sold to soap companies for soap production. Therefore, the used oil for biodiesel production, i.e., rendered PF or WCO must be compensated by the marginal supplier(s). Figures 2 and 3 show the system boundaries of the CLCA performed for PF- and WCObiodiesel fuels in this study, respectively. Accordingly, the following two scenarios were defined:

\section{Increased combustion of B5-PF (consequential modeling)}

As mentioned earlier, the most common use of PF in Iran is in the poultry feed production. Therefore, when PF is used for biodiesel production, its demand in the market is bound to increase and consequently two situations may arise: 1) increased production of PF to meet the new demands or, 2) using alternative sources to PF by poultry feed producers. However, since the economic value of PF is far lower than that of poultry meet, it could be assumed that an increase in the demand for PF and consequently in its price would not serve as a motivation for the poultry farmers to increase their poultry production to keep up with the PF demand in the market. On the contrary, feed producers would be better off finding a substitute for PF. Such assumption was in fact previously supported by the findings of Jørgensen et al. (2012). Accordingly, they reported that the total fat removed from the feed (by excluding $1 \mathrm{~kg}$ of PF from the feed market) could be compensated by $0.67 \mathrm{~kg}$ of palm oil and $0.34 \mathrm{~kg}$ of soybean oil (Jørgensen et al., 2012). In the present study, the marginal supplier of palm oil was assumed to be Malaysia from which most of palm oil is imported into Iran (Fig. 3). In fact, Malaysia is identified as the marginal oil supplier in the global market by many researchers (Schmidt and Weidema, 2008; Escobar et al., 2014). For the soybean oil, Argentina was chosen as the marginal supplier of oil due to the fact that this country was the main producer of the soybean oil imported to Iran. It is also worth quoting that in the present study, it was assumed that agricultural production was increased by only area expansion instead of intensification. This was attributed to the fact that the latter would be more uncertain and complicated since it would require prediction of the changes in type and amount of inputs needed to increase crop yields (Escobar et al., 2014).

Scenario $\mathrm{C}$ also has another important indirect aspect which is the production of palm kernel meal and soybean meal as co-products of the oil extraction processes (Fig. 3). These meals are in fact the indirect functions of the system since they could be used as animal feed. On the other hand, Brazil is generally considered as the long-term marginal supplier of soybean meal (Reinhard and Zah, 2011) (and is also the largest soybean meal exporter to Iran). Consequently, the additional meals produced under this scenario (by Malaysia and Argentina) are expected to partially decrease soybean meal production in Brazil (Fig. 3). Therefore, the amount of marginal meal (Soybean meal in Brazil) substituted by palm kernel meal or soybean meal was estimated according to the protein and energy contents of the meals reported by Reinhard and Zah (2011).

Finally, the loop between palm oil/palm kernel meal in Malaysia, soybean oil/meal in Argentina, and soybean oil/meal in Brazil were identified as presented in Figure 2. When the production of soybean meal in Brazil decreases, the amount of soybean oil (from Brazil) in the international market decreases as well, which is again compensated by the marginal supplier of oil, i.e., palm oil Malaysia. This loop iterates till the flows trend against zero, causing a net increase in production of palm oil in Malaysia $(62.35 \mathrm{~g})$ and a decrease in production of soybean meal in Brazil (95.22 g). 


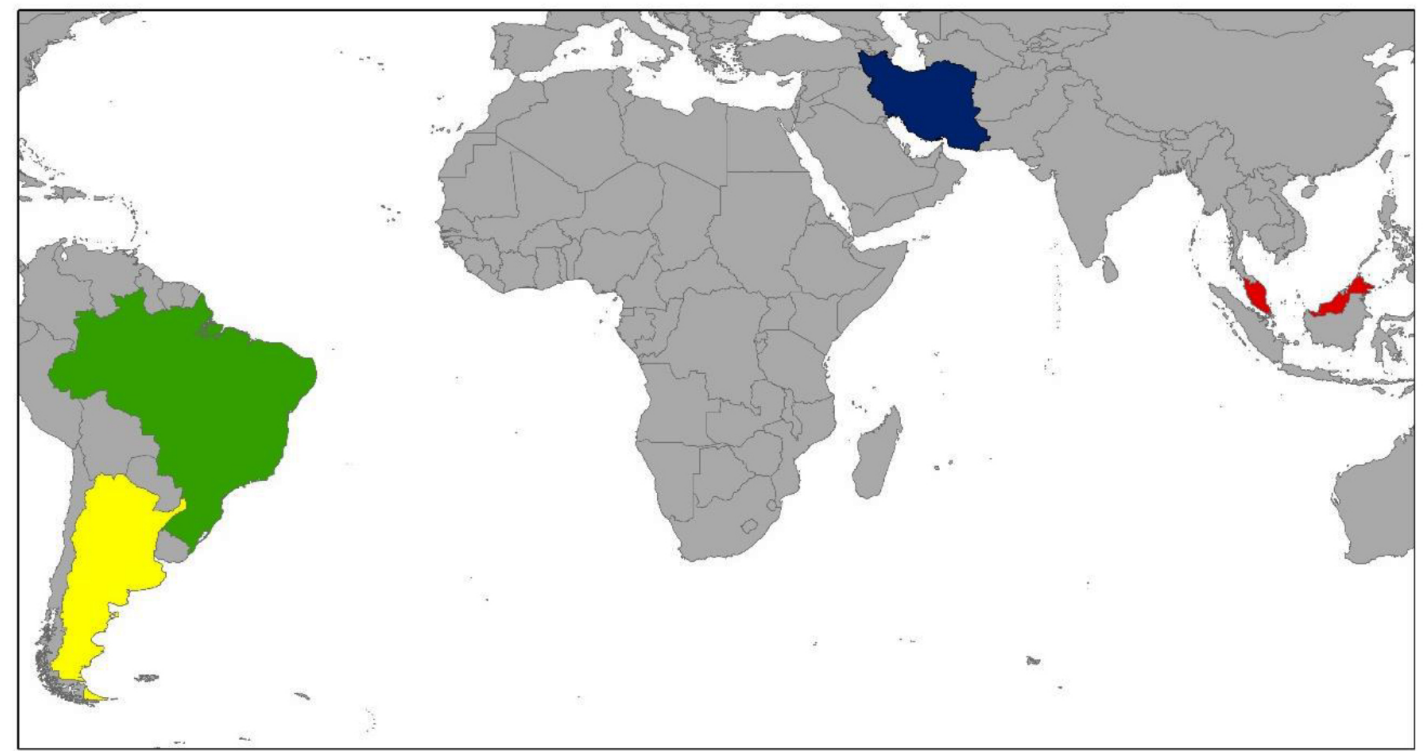

$\square$ Argentina $\square$ Brazil $\square$ Iran (Islamic Republic of) $\square$ Malaysia

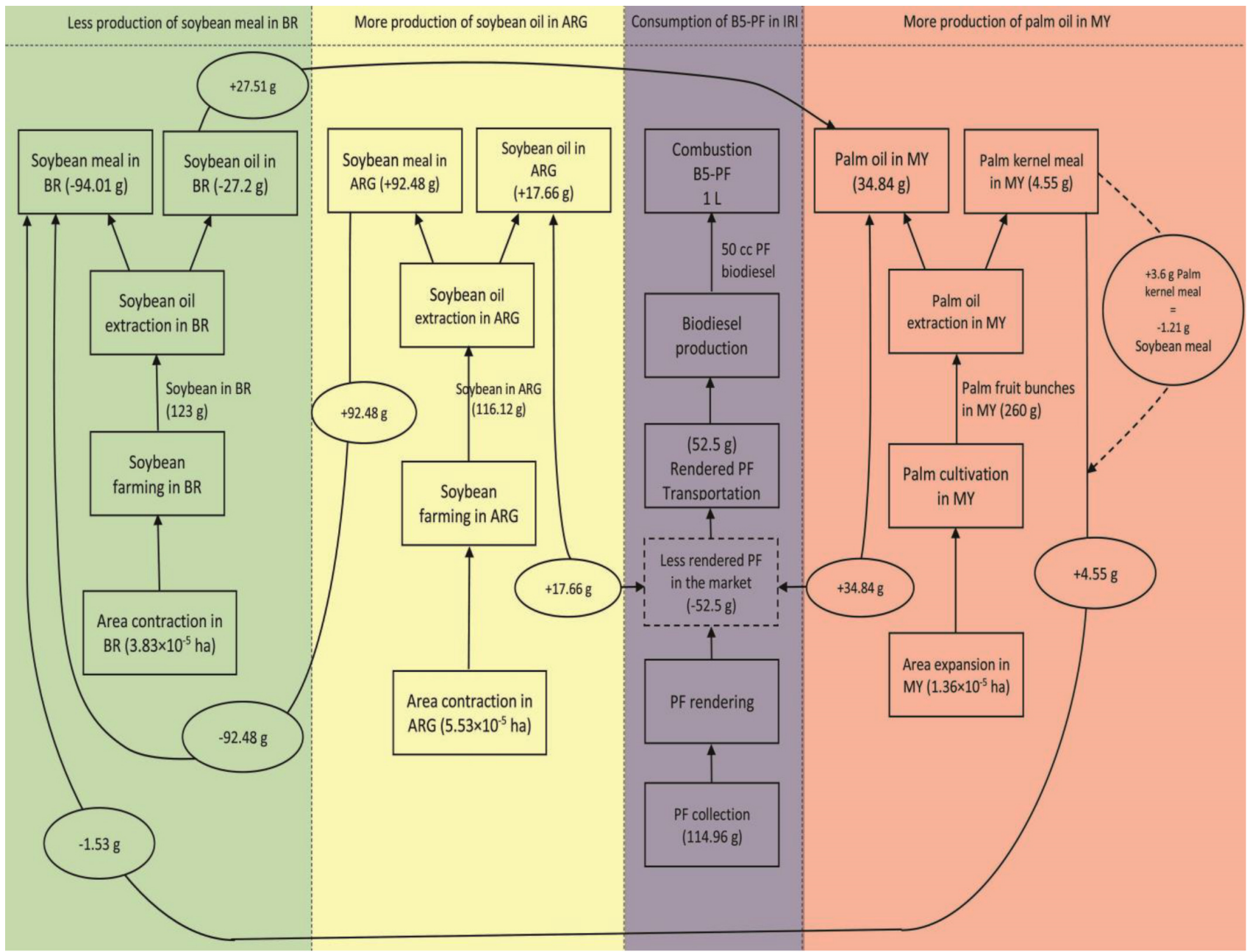

Fig.3. System delimitation of Scenario C. The loop between palm oil in Malaysia, soybean oil in Argentina and soybean meal in Brazil is generated by the consumption of 50 additional CC of biodiesel from PF in Iran. Values presented in the circles show the total amounts of meal and oil needs for balancing the loop. IRI: Iran (Islamic Republic of); BR: Brazil; MY: Malaysia; ARG: Argentina.

Please cite this article as: Rajaeifar M.A., Tabatabaei M., Abdi R., Latifi A.M., Saberi F., Askari M., Zenouzi A., Ghorbani M. Attributional and consequential environmental assessment of using waste cooking oil- and poultry fat-based biodiesel blends in urban buses: a real-world operation condition study. Biofuel Research Journal 15 (2017) 638-653. DOI: 10.18331/BRJ2017.4.3.3 


\section{Increased combustion of B5-WCO (consequential modeling)}

In scenario D, WCO was subjected to biodiesel production and therefore, the market would witness increases in WCO prices or lack of supply. Therefore, soap companies would tend to look for other economically reasonable substitutes for WCO such as palm oil. As shown in Figure 4, Malaysia was assumed as the marginal producer of palm oil. Accordingly, WCO was substituted by the marginal oil at the ratio of 1 to 1 (by weight). The idea of substitution of various oil feedstock such as rapeseed, sunflower, soybean, and palm oil for different applications in the market was previously introduced by Schmidt and Weidema (2008). However, this idea would not be logically applicable in the poultry feed industry (i.e., scenario $\mathrm{C}$ in which PF should be compensated by an appropriate amount of alternatives). Similar to scenario C, increasing palm oil production in Malaysia would result in more palm kernel meal delivered to the global market causing a decrease in the most frequentlyused protein source, i.e., soybean meal from Brazil. The amount of marginal meal (soybean meal in Brazil) substituted by palm kernel meal was also estimated according to the protein and energy contents of the meals reported by Reinhard and Zah (2011).

Finally, the loop between palm oil/palm kernel meal in Malaysia and soybean oil/meal in Brazil was assumed to iterate till the flows trend against zero. More specifically, when the production of soybean meal in Brazil decreases, the amount of soybean oil in the international market decreases as well, which is again compensated by the marginal supplier of oil, i.e., palm oil Malaysia. This loop would eventually cause a net increase in the production of palm oil in Malaysia (50.5 g) and a decrease in production of soybean meal in Brazil (2.21 g)

\subsubsection{Life cycle inventory}

\section{- Scenarios $A$ and $B$}

The foreground data set for collection, transportation, and transesterification of WCO and PF were collected through the course of this study. Moreover, the combustion data were examined through a set of test explained in Section 2.2. The restaurants (providing WCO), the stores (providing the raw PF), the rendering plants (providing rendered $\mathrm{PF}$ ), and biodiesel production center were located in Karaj metropolitan (Alborz province, Iran); $20 \mathrm{~km}$ west of the Iranian capital, Tehran. However, since the real-world driving tests were performed in Tehran, and also in order to avoid uncertainty in the transportation stage, the transportation distance between diesel stations and the real-world driving test garage as well as the distance between the biodiesel production center and the real-world driving test garage were disregarded in the calculations. While the collection of WCO and PF within the city as well as the transportation of WCO and rendered $\mathrm{PF}$ to the biodiesel production center were included in the calculations. These transportations were performed by the most common type of medium-sized pickup trucks in Iran (i.e., Nissan Junior) with the nominal capacity of 2.2 tons. Moreover, mineral oil transportation was assumed to be carried by pipelines from Marun oil field (located in the Khuzestan province of Iran: $30^{\circ} 51^{\prime} 13^{\prime \prime} \mathrm{N} 49^{\circ} 50^{\prime} 19^{\prime \prime} \mathrm{E}$ ) to Tehran province (Tehran Oil Refinery Company: $\left.35^{\circ} 32^{\prime} 29.9^{\prime \prime} \mathrm{N} 51^{\circ} 24^{\prime} 58.1^{\prime \prime} \mathrm{E}\right)$. Then, the refined diesel from the oil refinery was transported to the stations by $18000 \mathrm{~L}$ diesel tanker trucks.

While the foreground data set including all the inputs and their related emissions were calculated for each stage, the background data set for the production of all inputs were adopted from the Ecoinvent v.3.3 database. It should also be noted that since these scenarios (A and B) were attributional, the electricity consumption was modeled as an average of all electricity sources within the country (Production Mix) including the average distribution losses in the grid.

\section{- Scenarios $C$ and D}

The foreground data set for scenarios C and D encompassed three types of data, i.e., 1) collection, transportation, transesterification, and combustion of B5-WCO and B5-PF, and 2) agricultural fresh palm fruit bunch (FFB) production in Malaysia, soybean production in Brazil and Argentina, palm oil and kernel oil mill stages (including refining) in Malaysia, soybean mill stage in Brazil and Argentina, as well as 3) transportation of raw materials in these countries to the farms and oil mill plants along with palm oil and soybean oil transportation to Iran. These data sets are explained in more detail as follows:
(1) Similar data (from scenarios A and B) were used. The only marginal technology assumed in the biodiesel production stage was electricity generation. The marginal source of electricity in Iran was regarded as natural gas and the type of marginal technology was combined cycle power plants (with an efficiency of $60 \%$ and electricity distribution losses of $11 \%$ as recorded in the year 2016 (Tavanir, 2016)). The other inputs, biodiesel production technology, and transportation means and distances were assumed not to be affected by differing situations.

(2) The complete inventory for agricultural FFB cultivation, as well as palm oil and palm kernel oil refining in Malaysia were adopted from Schmidt (2007). However, the inventory for palm oil mill stage was gathered from Ecoinvent v.3.3 database since this inventory was recognized as the most comprehensive inventory on palm oil milling. Since the inventory contains one single process per each co-product, the original economic allocation was undone and processes were unified. The inventory data for agricultural soybean cultivation in Brazil was obtained from Schmidt (2007), while agricultural soybean cultivation in Argentina was adopted from Ecoinvent v.3.3 database. The inventory data for the soybean mill stage in Brazil was also acquired from Schmidt (2007), whereas the data published by Dalgaard et al. (2008) were used as the inventory source for the soybean mill stage in Argentina. It should be noted that land use change (LUC) emissions (i.e., emissions attributed to land transformation) were included in the agricultural stage of the applied inventories.

The inventory data related to $1 \mathrm{MJ}$ marginal electricity at the point-ofuse in Malaysia and Brazil were adopted from Schmidt (2007). This inventory data included the efficiency of the marginal technology and the electricity distribution losses in the grid (Schmidt, 2007). The margina electricity in Argentina was defined as natural gas-based electricity produced in combined cycle power plants (with an efficiency of $60 \%$ and electricity distribution losses of 14\% as recorded in the year 2010 (Energy efficiency report, 2016)).

(3) Transportation of agricultural products to the oil mill plants, i.e., FFB and soybean as well as transportation of inputs to the agricultural farms and oil mill plants were also considered in the applied inventories. Transportation of palm oil and palm kernel meal from the oil mill plants to the harbor were assumed to performed by railways (distance of $500 \mathrm{~km}$ ) as suggested by Jørgensen et al. (2012). For soybean oil and meal in Argentina, Rosario Harbor was recognized as the port for exporting soybean oil and meal (Dalgaard et al., 2008; Panichelli et al., 2009). Therefore, transportation distance from soybean mill plants to Rosario Harbor was adopted from Panichelli et al. (2009). More specifically, they pointed that the soybean mills and transesterification plants were located in the same place at the vicinity of Rosario Harbor and that the distance between the transesterification plants to the port of Rosario was $100 \mathrm{~km}$. The transportation means of soybean oil to the harbor was assumed to be carried out by 28 -t trucks. Finally, the transportation of palm oil to Iran was assumed by transoceanic tankers (with an average vessel speed of 15 knots) from Port Kelang to Shahid Rajaee Port (with a distance of $5897 \mathrm{~km}$ ). Moreover, the transportation of soybean oil from Argentina to Iran was presumably carried out by transoceanic tankers as well (with an average vessel speed of 15 knots) from Rosario Harbor to Shahid Rajaee Port (with a distance of $15829 \mathrm{~km}$ )

\subsubsection{Life cycle impact assessment (LCIA)}

The life cycle impact assessment (LCIA) was carried out using SimaPro 8.4 software. Accordingly, Impact $2002+$ method was applied as the LCIA method. The mid-point impact categories included were: non-carcinogens, carcinogens, respiratory organics, ionizing radiation, ozone layer depletion, respiratory inorganics, aquatic ecotoxicity, terrestrial acidification/nitrification, terrestrial ecotoxicity, land occupation, aquatic acidification, aquatic eutrophication, global warming, non-renewable energy, and mineral extraction. These mid-point impact categories were finally structured into the four end-point damage categories of human health, ecosystem quality, climate change, and resources (Jolliet et al., 2003). It is also worth quoting that the method was updated in some aspects as follows:

Characterization factors for Climate Change damage category was updated based on a time horizon of 100 years reported by Myhre et al (2013). 


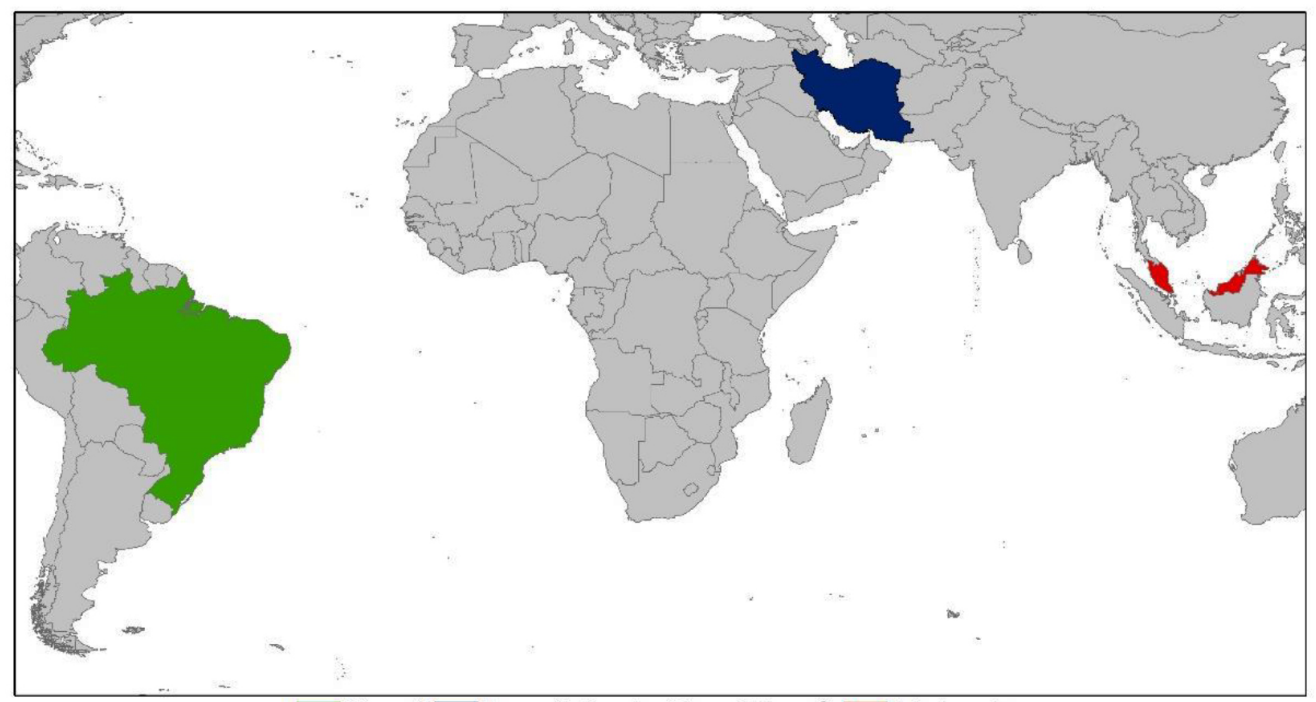

Brazil —Iran (Islamic Republic of) $\square$ Malaysia

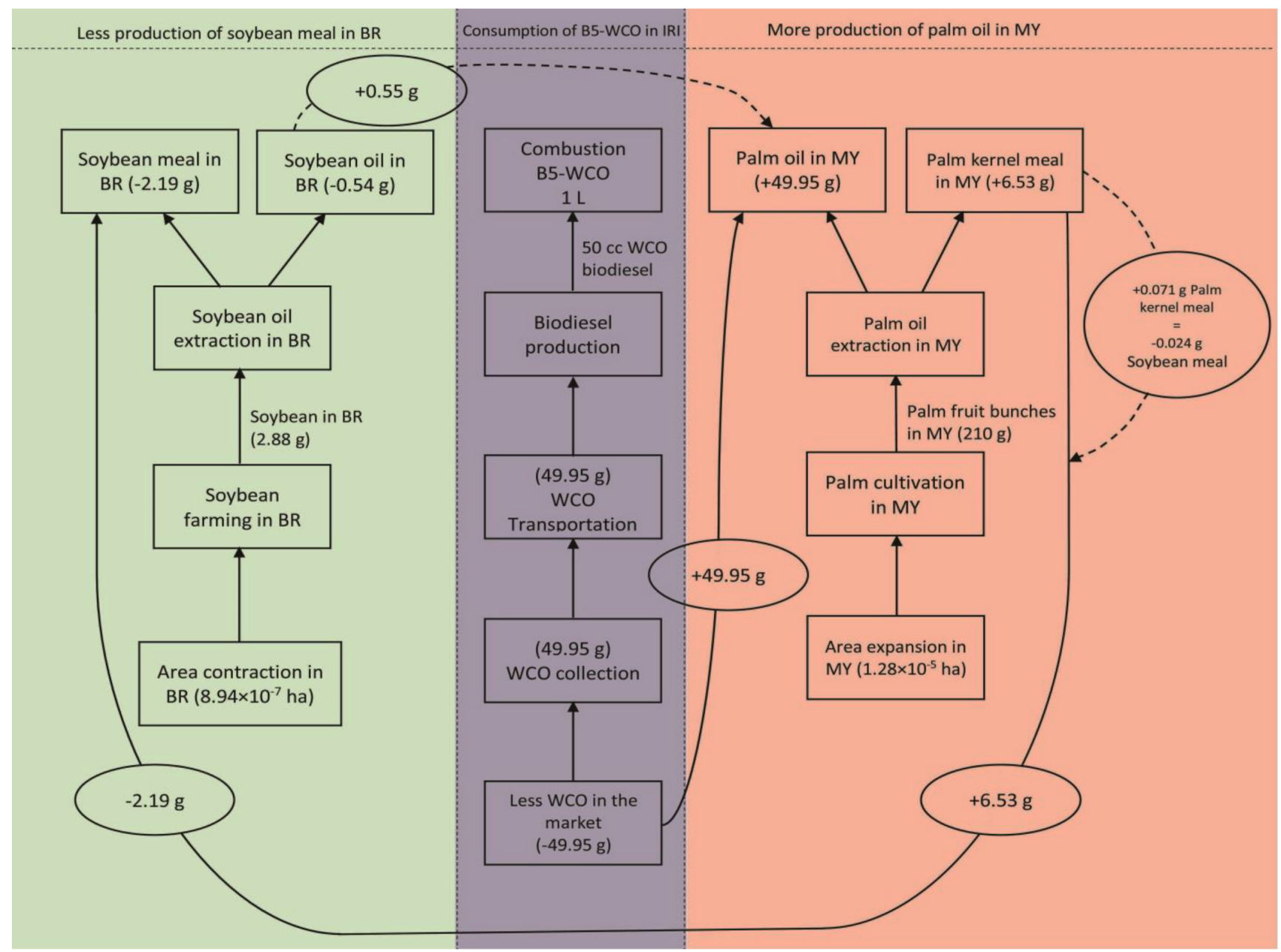

Fig.4. System delimitation of Scenario D. The loop between palm oil in Malaysia and soybean meal in Brazil is generated by the consumption of 50 additional CC of biodiesel from WCO in Iran. Values presented in the circles show the total amounts of meal and oil needs for balancing the loop. IRI: Iran (Islamic Republic of); BR: Brazil; MY: Malaysia.

Please cite this article as: Rajaeifar M.A., Tabatabaei M., Abdi R., Latifi A.M., Saberi F., Askari M., Zenouzi A., Ghorbani M. Attributional and consequential environmental assessment of using waste cooking oil- and poultry fat-based biodiesel blends in urban buses: a real-world operation condition study. Biofuel Research Journal 15 (2017) 638-653. DOI: 10.18331/BRJ2017.4.3.3 

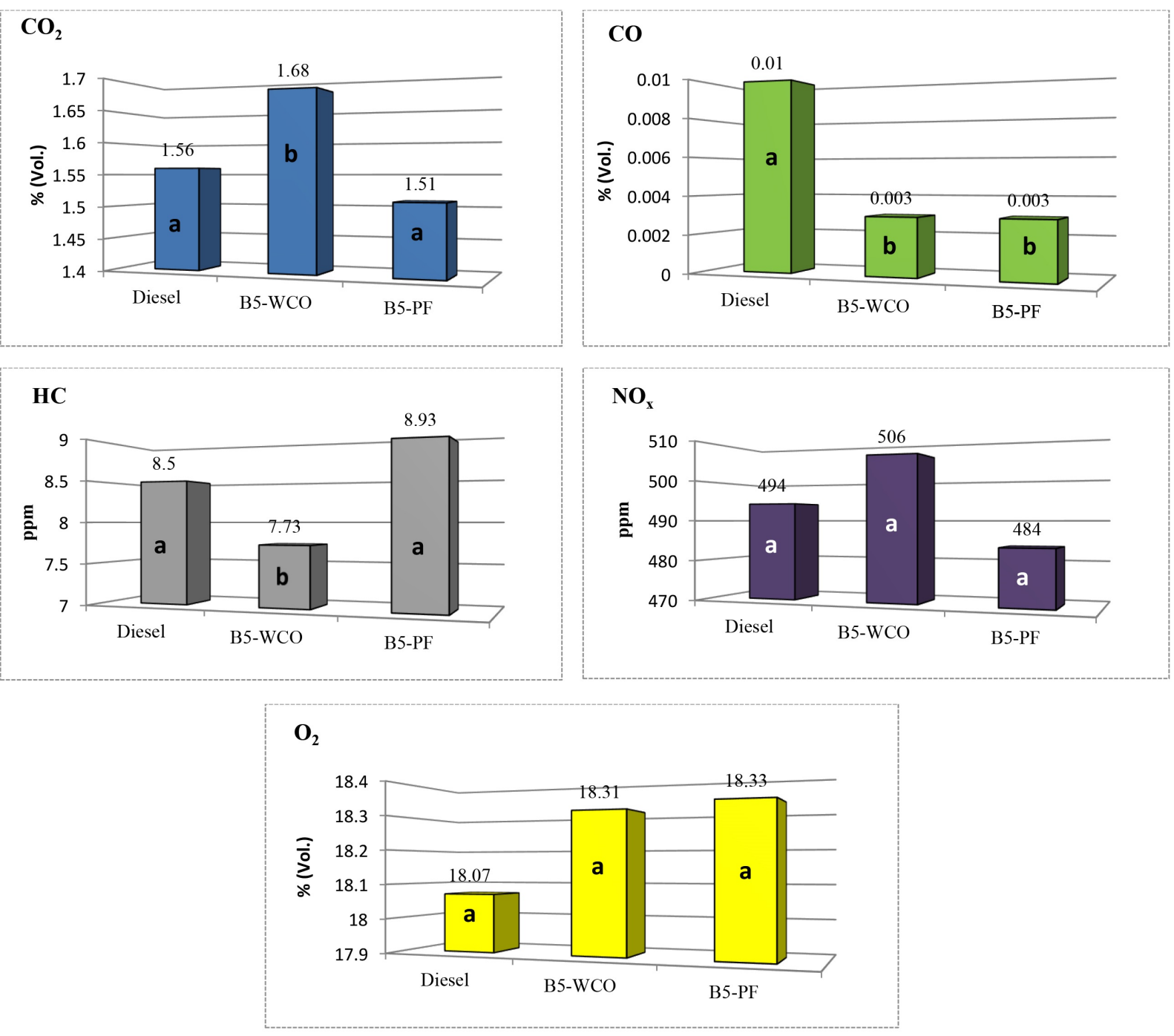

Fig.5. Post hoc MANOVA results for idle operation mode (low-speed of the engine).

- Aquatic eutrophication and aquatic acidification damage factors (from mid-point to end-point level) were updated based on Humbert et al. (2014). Moreover, characterization factors related to aquatic eutrophication were updated based on 'undefined watershed' instead of 'P-limited watershed'.

\section{Results and discussions}

\subsection{Real-world operation test results: idle-emissions}

The properties of the biodiesel fuels produced from WCO and PF were in accordance with the ASTM D6751 standard (data not shown). The results of multivariate analysis of variance (MANOVA) for combustion stage at the lowspeed of the engine under idle condition showed that there was a significant difference between the investigated fuels (i.e., B5-WCO, B5-PF, and diesel) in terms of $\mathrm{CO}, \mathrm{CO}_{2}$, and $\mathrm{HC}$ emissions at a confidence interval level of $99 \%$. In order to inspect the differences among the treatment means in more details, a post hoc test (i.e., Duncan) was performed and the results are shown in Figure 5. It should also be noted that all the variables (including the non-significant ones) have been presented in the figure. Accordingly, compared with the petroleum diesel, B5-WCO significantly increased $\mathrm{CO}_{2}$ emissions while reduced $\mathrm{CO}$ and $\mathrm{HC}$ emissions at low-speed of engine under the idle operation mode. This could be ascribed to the higher oxygen content of biodiesel (compared with petroleum diesel) leading to improved combustion efficiency and consequently reduced $\mathrm{CO}, \mathrm{HC}$, and $\mathrm{PM}$ emissions (Rajaeifar et al., 2017). Moreover, the B5-PF fuel blend showed no significant difference with petroleum diesel except in the case of $\mathrm{CO}$ emissions. In a similar study by Tica et al. (2010) who also investigated biodiesel emissions under idle condition of urban busses, they reported a decrease in $\mathrm{CO}, \mathrm{CO}_{2}, \mathrm{SO}_{2}$, and soot emissions when $\mathrm{B} 100$ was used. However, the authors failed to offer any explanations about the $\mathrm{CO}_{2}$ reduction observed in their study. The results obtained by Bai et al. (2016) were also in line with those of the present study. More specifically, they also reported a decrease in $\mathrm{CO}$ and $\mathrm{HC}$ emissions when using B10, B20, and B50 (compared with the emissions recorded for B4) on urban busses under idle operation mode.

The results of the MANOVA for the combustion stage at high-speed of the engine under the idle condition showed that there was a significant difference between the investigated fuels (i.e., B5-WCO, B5-PF, and diesel) in terms of the tailpipe emissions of $\mathrm{CO}_{2}, \mathrm{HC}$ (both at confidence interval level of $99 \%$ ), as well as $\mathrm{O}_{2}$ and $\mathrm{NOx}$ (both at confidence interval 


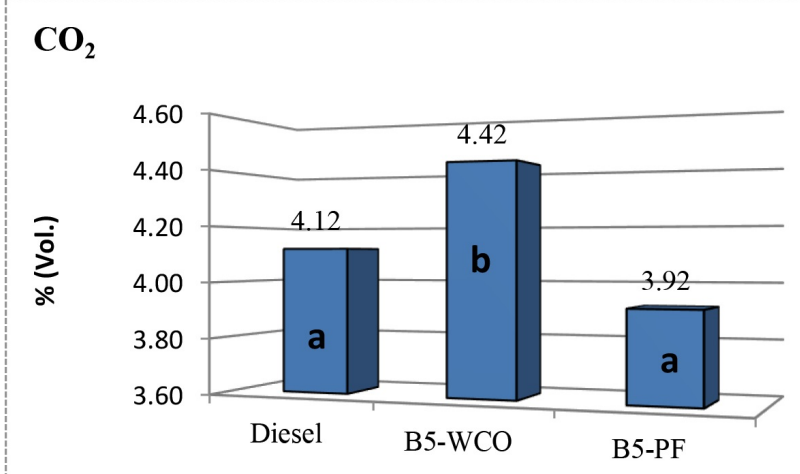

HC

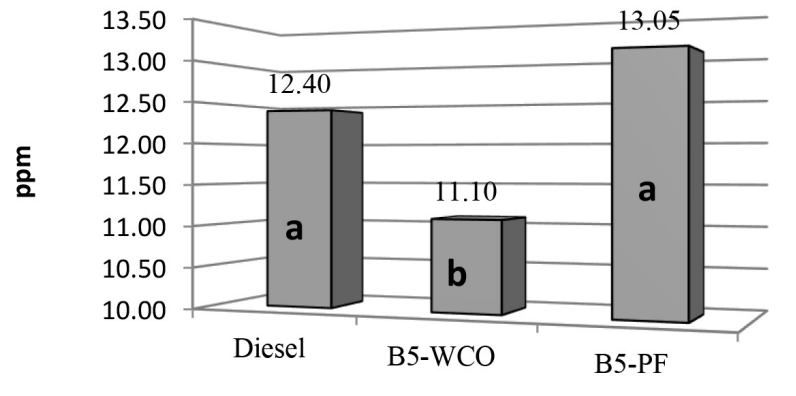

CO

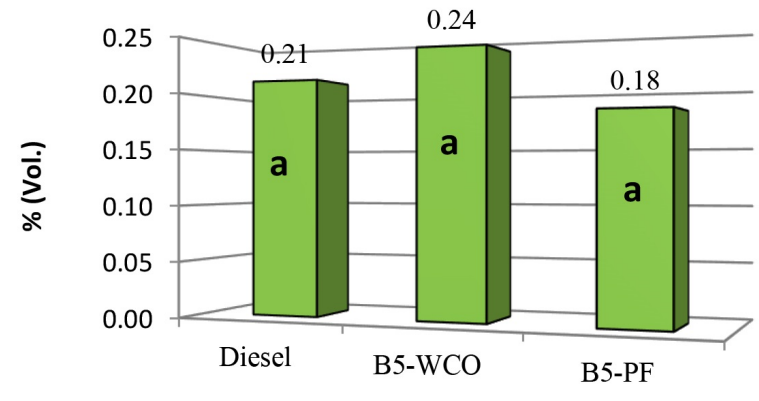

$\mathrm{NO}_{\mathbf{x}}$

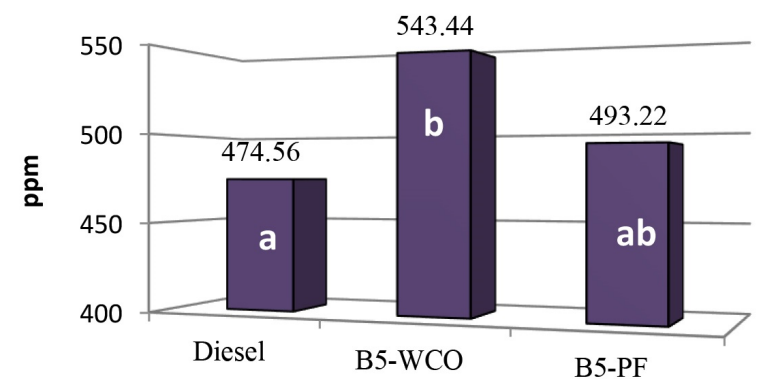

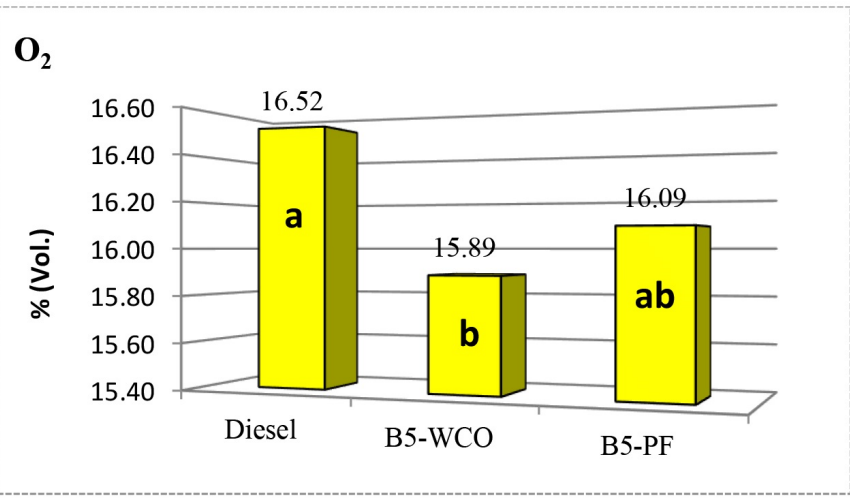

Fig.6. Post hoc MANOVA results for idle operation mode (high-speed of the engine).

level of 95\%). Similar to the results of the low-speed engine operation and in order to inspect the differences among the treatment means under high-speed engine operation in more details, a post hoc test (i.e., Duncan) was performed and the results are shown in Figure 6. Like in Figure 5, all the variables (including the non-significant ones) were also included in this figure as well. Accordingly, compared with the petroleum diesel, the B5-WCO fuel blend significantly increased $\mathrm{CO}_{2}$ and $\mathrm{NO}_{x}$ emissions while reduced $\mathrm{O}_{2}$ and $\mathrm{HC}$ emissions at low-speed of engine under idle operation mode. The increase in $\mathrm{CO}_{2}$ emissions as well as the decrease in $\mathrm{O}_{2}$ and $\mathrm{HC}$ emissions could be justified by the impact of biodiesel on improving the efficiency of combustion as previously elaborated. The decreased amount of $\mathrm{O}_{2}$ in the tailpipe emissions could be indicative of oxygen reaction with either/both of $\mathrm{C}$ atoms or $\mathrm{N}_{2}$. In this context, increasing temperature values at high-speed engine operation in the idle-mode must have facilitated NOx formation especially for the oxygenated fuels. On the contrary, the B5-PF fuel blend showed no significant differences with the emissions recorded for the petroleum diesel. Moreover, the difference between B5-PF and B5-WCO in terms of $\mathrm{O}_{2}$ and NOx emissions were not significant either. These observations could be attributed to the higher kinematic viscosity of PF biodiesel vs. WCO biodiesel $\left(4.3 \times 10^{-4}\right.$ $\mathrm{m}^{2} / \mathrm{s} v$ s. $3.6 \times 10^{-4} \mathrm{~m}^{2} / \mathrm{s}$, respectively) (Knothe et al., 2006).

$\mathrm{k}$-value index (absorption) is in fact a measure for smoke opacity in diesel engines (Serrano et al., 2008). More specifically, smoke opacity instruments measure the optical properties of diesel smoke, providing an indirect way of measuring diesel particulate emissions. In fact, $\mathrm{k}$-value is an indication of engine black carbon emissions throughout low-speed to high-speed idle operation. Therefore, k-value was separately analyzed using ANOVA and the results were reported in Figure 7. As presented, compared with the petroleum diesel, the B5-WCO fuel blend significantly decreased $\mathrm{k}$-value of the engine under the idle operation mode while there was no significant difference between the B5-PF and diesel fuels. Moreover, the B5-WCO fuel blend was associated with a lower k-value compared with the B5-PF fuel blend. Overall, the differences observed 
between the B5-WCO and B5-PF fuel blends for all the measured emissions in both low and high speeds of engine under idle operation mode could be attributed to the differences in their combustion quality mainly caused by the differences in the kinematic viscosity values of the fuels under investigation as previously mentioned.

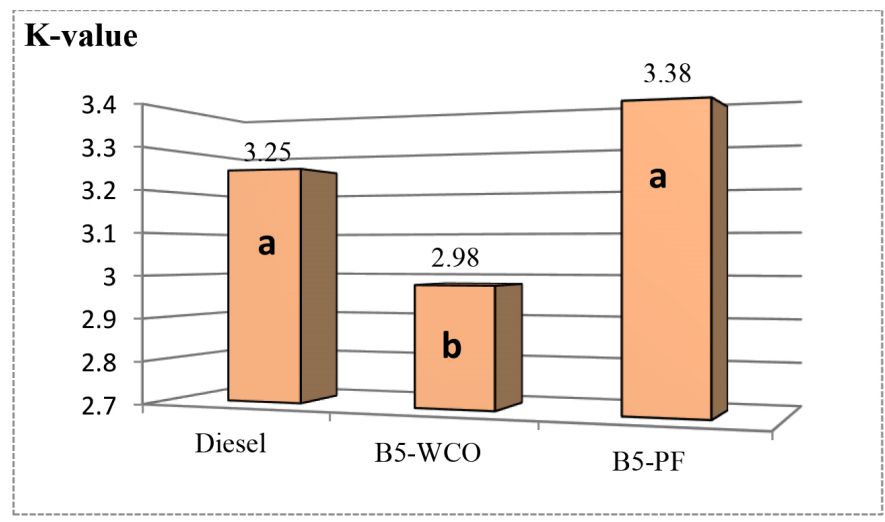

Fig.7. Post hoc K-value results for idle operation mode.

\subsection{ALCA results}

The results of the ALCA, i.e., comparative analysis of scenarios A and B are shown in Figure 8. Based on the results obtained, using 1 L B5-WCO showed a lower environmental burden in human health, ecosystem quality and resources damage categories. While, the situation was opposite for climate change damage category in which $1 \mathrm{~L}$ B5-PF had lower impacts on the environment.

When studying the impacts of the tested fuels on human health damage category, it was evident that the combustion stage had the highest share on this impact category with shares of $94.1 \%$ and $93.9 \%$ for B5-WCO and B5-PF blends, respectively. The results also revealed that B5-PF combustion led to higher emissions compared with B5-WCO. In fact, the higher level of PM emissions (represented by the K-value) was responsible for the higher level of combustion emissions for the B5-PF blend. Following by the combustion stage, diesel production and transportation to the station (referred to as diesel P\&T) was ranked second which had the highest impact on human health damage category for the investigated fuel blends, i.e., $5.80 \%$ and $5.59 \%$ for B5-WCO and B5-PF blends, respectively. Based on the results, emissions from diesel $\mathrm{P} \& \mathrm{~T}$ in the B5-PF life cycle stood at 4.78E-07 DALY/FU which was higher than that of B5-WCO. Obviously, this was originated from the higher level of diesel consumption in the B5-PF life cycle. More specifically, in the PF rendering stage, the rendering process is generally performed using watercooking method in which diesel is used for heating water used in the process. This extra amount of diesel consumption was considered in the diesel P\&T.

As mentioned earlier, the B5-WCO fuel blend showed a lower impact on ecosystem quality damage category compared with the B5-PF blend. Similar to human health damage category, the combustion stage by $77.10 \%$ and $77.31 \%$ for the B5-WCO and B5-PF fuel blends, respectively, followed by diesel P\&T by $18.92 \%$ and $19.05 \%$ for the B5-WCO and B5-PF fuel blends, respectively, had the highest shares in the total life cycle emissions in this damage category. More specifically, no difference in the respected emissions was observed for the combustion stage of the fuels investigated. While, the emissions associate with the diesel P\&T was higher in the B5-PF life cycle due to the higher level of diesel consumption in PF rendering plants. Moreover, biodiesel production reduced the impacts on this damage category due to the avoided emissions achieved by glycerin production. It is also worth quoting that since the amount of glycerin production was higher for WCO biodiesel, therefore, the reduction achieved was higher for B5-WCO fuel blend compared with the B5-PF fuel blend.

Compared with the B5-WCO fuel blend, the B5-PF fuel blend showed a lower environmental impact when analyzing climate change damage category. Similar to the previous damage categories reported earlier, the combustion stage followed by diesel P\&T had the highest shares in the total life cycle emissions of the studied fuels. Based on the data presented in Figure 8, the impacts of diesel P\&T for B5-WCO fuel blend was lower than that of the B5-PF fuel blend. Furthermore, the emissions reduction rate achieved in this impact category through glycerin production in biodiesel production stage was higher for the B5-WCO fuel blend. Nevertheless, what made the B5-WCO fuel blend less environmentally-friendly in this damage category was the combustion stage. More specifically, based on the results obtained in the real-world operation test conducted herein, the B5-WCO fuel blend significantly increased $\mathrm{CO}_{2}$ emissions compared with the $\mathrm{B} 5-\mathrm{PF}$ fuel blend and petroleum diesel. These emissions finally led to a higher global warming contribution and consequently higher climate change impacts in case of B5-WCO fuel blend compared with the B5-PF fuel blend. It is also worth quoting that when calculating the GHG emissions through the course of this study, the often used term of 'biogenic' GHG emissions were not considered for neither of the fuels. This was not taken into account in order to avoid any confusion with respect to the set boundaries as well as uncertainties in the origin of the WCO and the amount of biogenic $\mathrm{CO}_{2}$ emitted through the B5 blends combustion.

The results of resources damage category (Fig. 8) also indicated that lower resources were extracted during the B5-WCO life cycle. More than $99 \%$ of the environmental burdens in this damage category was originated from the diesel P\&T. Accordingly, the higher amount of diesel consumption in the B5-PF life cycle led to the higher impacts of this fuel blend on this damage category. Overall, the environmental hotspots in the B5-WCO and B5-PF life cycles were identified as the combustion stage as well as the diesel P\&T. Therefore, improving the combustion quality of the B5-PF fuel blend by using some additives such as expanded polystyrene (Rajaeifar et al., 2017) and/or using natural gas burners in PF rendering plants could be suggested.

\subsection{CLCA results}

Figure 9 illustrate the results of the CLCA of scenarios C and D. The results for human health damage category showed that the B5-WCO fuel blend had a significantly lower environmental impacts on this damage category compared with the B5-PF fuel blend. This was mainly due to the fact that when using $1 \mathrm{~L} \mathrm{B5-PF}$ fuel blend (Fig. 3), $52.5 \mathrm{~g}$ PF would be removed from the market out of which $17.66 \mathrm{~g}$ soybean oil would be imported from Argentina (and also $34.84 \mathrm{~g}$ palm oil would be imported from Malaysia) in order to compensate for the oil removed from the market. Importing $17.66 \mathrm{~g}$ soybean oil from Argentina would imply a reduction in soybean meal production in Brazil as $92.48 \mathrm{~g}$ or in another word, $26.73 \mathrm{~g}$ reduction in Brazilian soybean oil production. Although these reductions would imply a reduction in emissions due to a decrease in Brazilian soybean production, the amount of $26.73 \mathrm{~g}$ reduced soybean oil in Brazil must be compensated again by palm oil from Malaysia (known as indirect FFB cultivation in Malaysia). This loop would finally iterate against zero and emit more emissions to the environment on this damage category due to the oil compensation by palm oil (the final amount of needed palm oil would stand at $62.35 \mathrm{~g}$ ) (Fig. 3). More specifically, the emissions of particulates $<2.5 \mu \mathrm{m}$ (in palm oil mill stage in Malaysia) and ammonia emissions (in FFB cultivation in Malaysia) were responsible for $45 \%$ of the environmental burdens in this damage category when analyzing soybean oil imports from Argentina. It should be noted that these indirect emissions, i.e., indirect emission caused by FFB cultivation in Malaysia, were included in soybean oil import from Argentina. The situation was different when using $1 \mathrm{~L}$ B5-WCO fuel blend, in which $49.95 \mathrm{~g} \mathrm{WCO}$ would be removed from the market. This amount of oil removed would finally be compensated for by importing $50.5 \mathrm{~g}$ palm oil from Malaysia. It is also worth quoting that the higher level of emissions (attributed to human health) through the combustion stage could be considered as the other reason marking the B5$\mathrm{PF}$ fuel blend as less eco-friendly in this damage category. Thus, improving the combustion quality through using combustion-improving additives would be suggested as a strategy to enhance the overall rating of this scenario.

When studying ecosystem quality damage category, it was evident that the emissions originated from soybean oil import from Argentina as well as those of the combustion stage highlighted the B5-PF fuel blend as less ecofriendly compared with the B5-WCO fuel blend. More specifically, when analyzing soybean oil import from Argentina, it was identified that more 

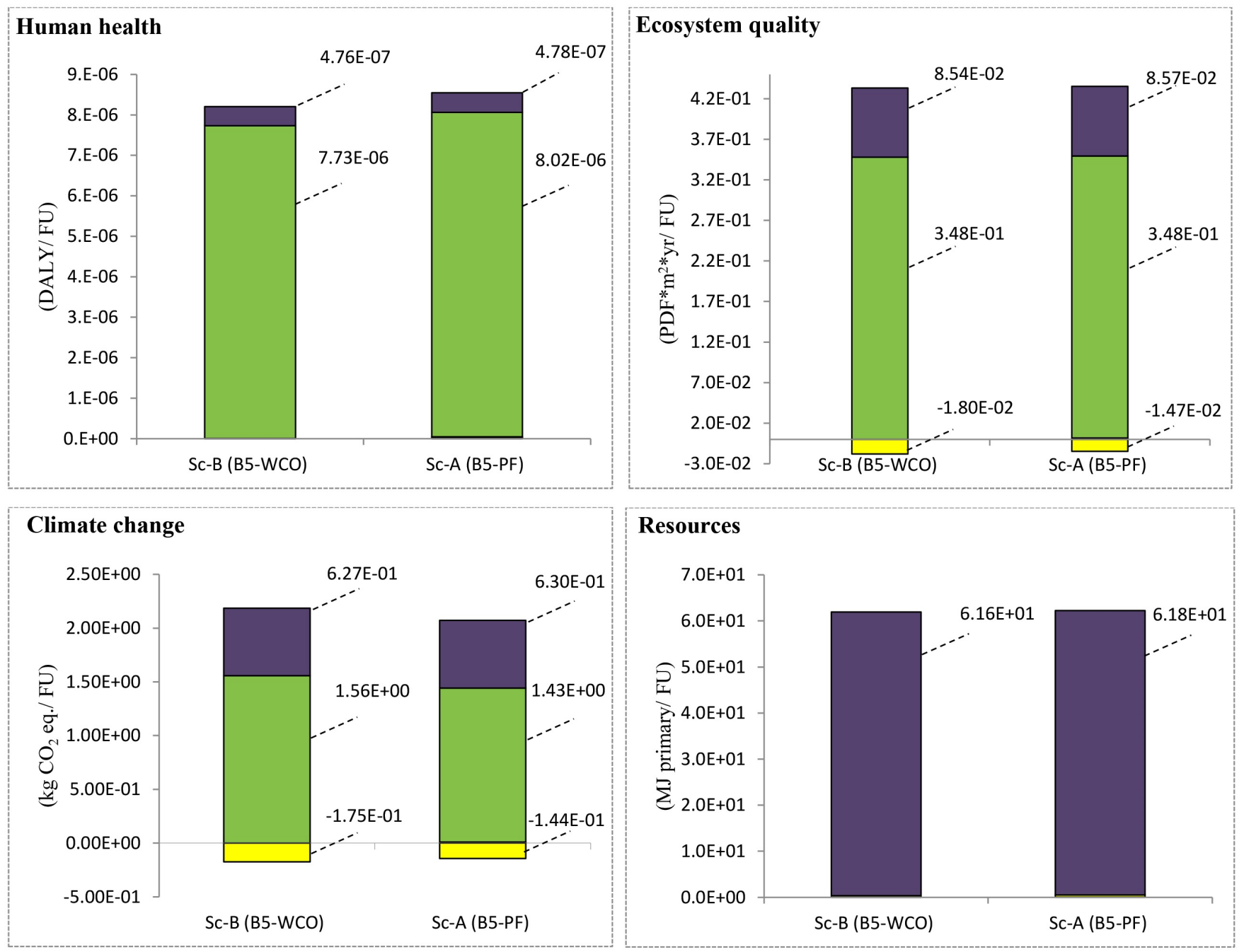

Transportation $\square$ Oil extraction $\square$ Biodiesel production $\square$ Combustion $\square$ Diesel P\&T

Fig.8. Results of ALCA for different damage cetegories studied. Sc-A (B5-PF): Combustion of B5-PF; Sc-B (B5-WCO): Combustion of B5-WCO.

than $97 \%$ of the emissions in this damage category were originated from land occupation through FFB cultivation (indirect FFB cultivation) in Malaysia. This would imply the effect of indirect emissions originated from FFB cultivation in Malaysia in order to compensate for the lower soybean oil production in Brazil (which was the result of increased soybean oil production in Argentina).

Analyzing resources damage category showed that higher amounts of resources were extracted throughout the B5-PF life cycle compared with the life cycle of B5-WCO fuel blend. More specifically, importing soybean oil from Argentina in the B5-PF life cycle was the driving factor for this higher impact on the environment. However, the effect of indirect increase in palm oil production (i.e., indirect FFB cultivation) in Malaysia only had a share of $22.5 \%$ out of the total emissions originated from soybean oil import (from Argentina). In fact, the higher amounts of agricultural inputs (i.e., fertilizers and diesel) in soybean cultivation in Argentina could be regarded responsible for this high effect.

The results of climate change damage category however, showed a different trend compared with the above-mentioned damage categories. In further details, compared with the B5-WCO life cycle, the B5-PF life cycle showed a significantly lower contribution to global warming and consequently to climate change damage category. In better words, in comparison with the B5-WCO fuel blend, the lower amounts of GHG emissions by palm oil import from Malaysia as well as the lower GHG emissions from the combustion stage in the B5-PF life cycle were responsible for the lower impacts of the B5-PF fuel blend on this damage category. On the other hand, and based on the data presented in Figure 9, importing soybean oil from Argentina reduced the climate change impacts by $0.84 \mathrm{~kg} \mathrm{CO}_{2}$ eq./FU. This was mainly due to fact that importing soybean oil from Argentina would lead to a reduction in soybean meal/oil in Brazil and consequently, reduced LUC emissions originated from agricultural soybean production in Brazil. It is also worth mentioning that the reduction in LUC emissions originated from reduced soybean cultivation in Brazil was higher than that of increased LUC emissions from the indirect increasing of FFB cultivation in Malaysia in order to compensate for the reduced amount of oil in the market in the B5PF life cycle (i.e., $26.73 \mathrm{~g}$ reduced soybean oil in Brazil must again be compensated for by palm oil from Malaysia).

Finally, and based on the findings of the present study, the selection of B5-WCO fuel blend as an alternative for petroleum diesel could be recommended to policy-makers as an environmentally-friendly strategy. It should be stressed that such a conclusion would be reliable as long as the marginal suppliers of oil would be Malaysia and by introducing another marginal supplier of oil different conclusions might be reached. This is also 

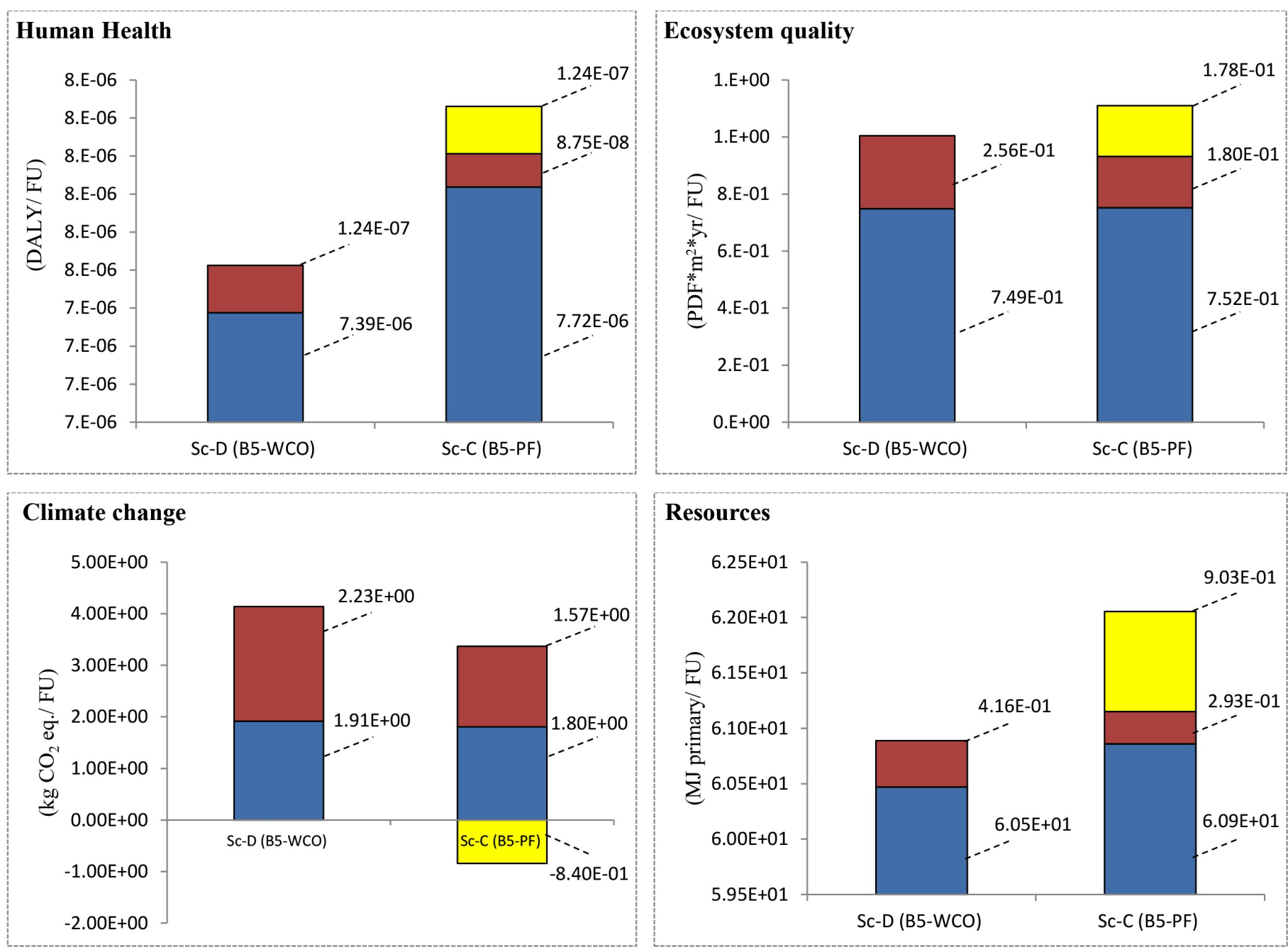

B5 Combustion

Palm oil import from MY $\quad \square$ Soybean oil import from ARG

Fig.9. Results of CLCA for different damage cetegories studied. Sc-C (B5-PF): Increased combustion of B5-PF; Sc-D (B5-WCO): Increased combustion of B5-WCO.

true about importing soybean oil (for poultry feed) from other countries rather than Argentina.

\section{Conclusions}

The present study was aimed at evaluating the emissions attributed to WCOand PF-based biodiesel when used in urban buses during idle operation mode. Moreover, the attributional and consequential environmental impacts of using B5-WCO and B5-PF fuel blends were also evaluated through a well to wheel LCA by considering the real-world condition combustion data using ten urban buses. The results of the ALCA showed that using $1 \mathrm{~L}$ B5-WCO fuel blend could potentially reduce the environmental burdens in human health, ecosystem quality, and resources damage categories compared with using the B5-PF fuel blend. The situation was opposite for climate change damage category in which the application of $1 \mathrm{~L} \mathrm{B5}-\mathrm{PF}$ fuel blend had a lower impact on the environment. Overall, the environmental hotspots in the B5-WCO and B5-PF life cycles were identified as the combustion stage as well as the diesel P\&T.
When considering using the B5-WCO and B5-PF fuel blends on a consequential perspective, the results obtained revealed that using $1 \mathrm{~L} \mathrm{B5}$ WCO fuel blend could potentially reduce the environmental burdens in human health, ecosystem quality, and resources damage categories. While, the situation was different for climate change damage category in which the application of $1 \mathrm{~L}$ B5-PF fuel blend had a lower impact on the environment. Finally, it could be concluded that the application of the B5-WCO fuel blend as an alternative for petroleum diesel could be an environmentallyfriendly decision at the policy level. It is needless to mention that these recommendations would be different if the marginal suppliers of oil would be different from the countries considered in the present study, i.e., Malaysia and Argentina.

\section{References}

[1] Aghbashlo, M., Tabatabaei, M., Mohammadi, P., Khoshnevisan, B. Rajaeifar, M.A., Pakzad, M., 2017. Neat diesel beats waste-oriented 
biodiesel from the exergoeconomic and exergoenvironmental point of views. Energy Convers. Manage. 148, 1-15.

[2] Al-lwayzy, S.H., Yusaf, T., 2017. Diesel engine performance and exhaust gas emissions using Microalgae Chlorella protothecoides biodiesel. Renewable Energy 101, 690-701.

[3] Altamirano, C.A.A., Yokoyama, L., de Medeiros, J.L., Araújo, O.d.Q.F., 2016. Ethylic or methylic route to soybean biodiesel? Tracking environmental answers through life cycle assessment. Appl. Energy 184, 1246-1263.

[4] Aoun, W.B., El Akkari, M., Flénet, F., Jacquet, F., Gabrielle, B., 2016. Recommended fertilization practices improve the environmental performance of biodiesel from winter oilseed rape in France. J. Cleaner Prod. 139, 242-249.

[5] Ashokkumar, V., Salim, M.R., Salam, Z., Sivakumar, P., Chong, C.T., Elumalai, S., Suresh, V., Ani, F.N., 2017. Production of liquid biofuels (biodiesel and bioethanol) from brown marine macroalgae Padina tetrastromatica. Energy Convers. Manage. 135, 351-361.

[6] Ashraful, A.M., Masjuki, H., Kalam, M., Fattah, I.R., Imtenan, S., Shahir, S., Mobarak, H., 2014. Production and comparison of fuel properties, engine performance, and emission characteristics of biodiesel from various non-edible vegetable oils: a review. Energy Convers. Manage. $80,202-228$.

[7] Attia, A.M., Hassaneen, A.E., 2016. Influence of diesel fuel blended with biodiesel produced from waste cooking oil on diesel engine performance. Fuel 167, 316-328

[8] Bai, A., Jobbágy, P., Popp, J., Farkas, F., Grasselli, G., Szendrei, J., Balogh, P., 2016. Technical and environmental effects of biodiesel use in local public transport. Transp. Res. Part D Trans. Environ. 47, 323-335.

[9] Caldeira, K., Wickett, M.E., 2003. Oceanography: anthropogenic carbon and ocean $\mathrm{pH}$. Nature 425, 365-365.

[10] Carneiro, M.L.N., Pradelle, F., Braga, S.L., Gomes, M.S.P., Martins, A.R.F., Turkovics, F., Pradelle, R.N., 2017. Potential of biofuels from algae: Comparison with fossil fuels, ethanol and biodiesel in Europe and Brazil through life cycle assessment (LCA). Renew. Sust. Energy Rev.73, 632-653.

[11] Clements, D., Gerpen, J., 2004. Biodiesel production technology. NRELNational Renewable Energy Laboratory. NREL/SR-510-36244.

[12] Cohen, A.J., Pope, C., 1995. Lung cancer and air pollution. Environ. Health Perspect. 103, 219-224.

[13] Covert, T., Greenstone, M., Knittel, C.R., 2016. Will we ever stop using fossil fuels? J. Econ. Perspect. 30, 117-137.

[14] Dalgaard, R., Schmidt, J., Halberg, N., Christensen, P., Thrane, M., Pengue, W.A., 2008. LCA of soybean meal. Int. J. Life Cycle Assess. $13,240$.

[15] Demirbas, A., 2007. Progress and recent trends in biofuels. Prog. Energy Combust. Sci. 33, 1-18.

[16] Dufour, J., Iribarren, D., 2012. Life cycle assessment of biodiesel production from free fatty acid-rich wastes. Renewable Energy 38, 155162.

[17] Escobar, N., Ribal, J., Clemente, G., Sanjuán, N., 2014. Consequential LCA of two alternative systems for biodiesel consumption in Spain, considering uncertainty. J. Cleaner Prod. 79, 61-73.

[18] Fernández-Tirado, F., Parra-López, C., Romero-Gámez, M., 2016. Life cycle assessment of biodiesel in Spain: comparing the environmental sustainability of Spanish production versus Argentinean imports. Energy Sustainable Dev. 33, 36-52.

[19] Fernandez, I.A.P., Liu, D.-H., Zhao, J., 2017. LCA studies comparing alkaline and immobilized enzyme catalyst processes for biodiesel production under Brazilian conditions. Resour. Conserv. Recycl. 119, 117-127.

[20] Finnveden, G., Hauschild, M.Z., Ekvall, T., Guinée, J., Heijungs, R., Hellweg, S., Koehler, A., Pennington, D., Suh, S., 2009. Recent developments in life cycle assessment. J. Environ. Manage. 91, 1-21.

[21] Gnansounou, E., Raman, J.K., 2016. Life cycle assessment of algae biodiesel and its co-products. Appl. Energy 161,300-308.

[22] Hearne, J.S., 2003. School bus idling and mobile diesel emissions testing: effect of fuel type and development of a mobile test cycle. Dissertation 1319. Rowan University.
[23] Hoornweg, D., Bhada-Tata, P., 2012. What a waste: a global review of solid waste management. Urban development series knowledge papers 15, 1-98.

[24] Humbert, S., Schryver, A.D., Bengoa, X., Margni, M., Jolliet, O., 2014. IMPACT 2002+:User Guide Draft for version Q2.22. (version adapted by Quantis). Lausanne, Switzerland.

[25] ISO, 2006a. In: Environmental Management. Life Cycle Assessment Principles and Framework. ISO 14040 International Standard International Organization for Standardization.

[26] ISO, 2006b. In: Environmental Management. Life cycle Assessment Requirements and Guidelines. ISO 14040 International Standard International Organization for Standardization.

[27] ISO:660, 2009. Animal and vegetable fats and oils - determination of acid value and acidity. International Organisation for Standardisation, Geneva, p. p. 660.

[28] Jolliet, O., Margni, M., Charles, R., Humbert, S., Payet, J., Rebitzer, G., Rosenbaum, R., 2003. IMPACT 2002+: a new life cycle impact assessment methodology. Int. J. Life Cycle Assess. 8, 324.

[29] Jørgensen, A., Bikker, P., Herrmann, I.T., 2012. Assessing the greenhouse gas emissions from poultry fat biodiesel. J. Cleaner Prod. 24, 85-91.

[30] Khoshnevisan, B., Rafiee, S., Tabatabaei, M., Ghanavati, H. Mohtasebi, S.S., Rajaeifar, M.A., 2017. Response to "Prognostication of energy use and environmental impacts for recycle system of municipal solid waste management”. J. Cleaner Prod. 164, 13761379.

[31] Khoshnevisan, B., Shafiei, M., Rajaeifar, M.A., Tabatabaei, M. 2016. Biogas and bioethanol production from pinewood pre-treated with steam explosion and $\mathrm{N}$-methylmorpholine-N-oxide (NMMO): A comparative life cycle assessment approach. Energy 114, 935-950.

[32] Knothe, G., Sharp, C.A., Ryan, T.W., 2006. Exhaust emissions of biodiesel, petrodiesel, neat methyl esters, and alkanes in a new technology engine. Energy Fuels 20(1), 403-408.

[33] Kumar, S., Singh, J., Nanoti, S., Garg, M., 2012. A comprehensive life cycle assessment (LCA) of Jatropha biodiesel production in India. Bioresour. Technol. 110, 723-729.

[34] Lardon, L., Helias, A., Sialve, B., Steyer, J.-P., Bernard, O., 2009 Life-cycle assessment of biodiesel production from microalgae. Environ. Sci. Technol. 43 (17), 6475-6481.

[35] Ma, F., Hanna, M.A., 1999. Biodiesel production: a review. Bioresour. Technol. 70, 1-15.

[36] Martins, L.D., da Silva Júnior, C.R., Solci, M.C., Pinto, J.P., Souza, D.Z., Vasconcellos, P., Guarieiro, A.L.N., Guarieiro, L.L.N., Sousa, E.T., de Andrade, J.B., 2012. Particle emission from heavy-duty engine fuelled with blended diesel and biodiesel. Environ. Monit. Assess. 184, 2663-2676.

[37] Mazzoleni, C., Kuhns, H.D., Moosmüller, H., Witt, J., Nussbaum, N.J., Chang, M.-C.O., Parthasarathy, G., Nathagoundenpalayam, S.K.K., Nikolich, G., Watson, J.G., 2007. A case study of real-world tailpipe emissions for school buses using a $20 \%$ biodiesel blend. Sci. Total Environ. 385, 146-159.

[38] Moecke, E.H.S., Feller, R., dos Santos, H.A., de Medeiros Machado, M., Cubas, A.L.V., de Aguiar Dutra, A.R., Santos, L.L.V., Soares, S.R., 2016. Biodiesel production from waste cooking oil for use as fuel in artisanal fishing boats: Integrating environmental, economic and social aspects. J. Cleaner Prod.135, 679-688.

[39] Mohammadi, P., Nikbakht, A.M., Tabatabaei, M., Farhadi, K., Mohebbi, A., 2012. Experimental investigation of performance and emission characteristics of DI diesel engine fueled with polymer waste dissolved in biodiesel-blended diesel fuel. Energy 46, 596-605

[40] Montrimaitė, K., Staniškis, J., Lapinskiené, A.M., 2010. Potential of greenhouse gas reduction producing and using biodiesel from fatty waste. Environ. Res. Eng. Manag. 54, 34-42.

[41] Myhre, G., Shindell, D., Bréon, F., Collins, W., Fuglestvedt, J., Huang, J., Koch, D., Lamarque, J., Lee, D., Mendoza, B., 2013. Anthropogenic and natural radiative forcing. Climate change 423.

[42] Nanaki, E., Koroneos, C., Xydis, G., Rovas, D., 2014. Comparative environmental assessment of Athens urban buses-Diesel, CNG and biofuel powered. Transp. Policy 35, 311-318. 
[43] Nanaki, E.A., Koroneos, C.J., 2012. Comparative LCA of the use of biodiesel, diesel and gasoline for transportation. J. Cleaner Prod. 20, 1419.

[44] Nerella, V.K.V., 2010. An analysis on vehicular exhaust emissions from transit buses running on biodiesel blends. University of Toledo.

[45] Panichelli, L., Dauriat, A., Gnansounou, E., 2009. Life cycle assessment of soybean-based biodiesel in Argentina for export. Int. J. Life Cycle Assess. 14, 144-159.

[46] Pleanjai, S., Gheewala, S.H., Garivait, S., 2009. Greenhouse gas emissions from production and use of used cooking oil methyl ester as transport fuel in Thailand. J. Cleaner Prod. 17, 873-876.

[47] Rajaeifar, M.A., Abdi, R., Tabatabaei, M., 2017. Expanded polystyrene waste application for improving biodiesel environmental performance parameters from life cycle assessment point of view. Renew. Sust. Energy Rev. 74, 278-298,

[48] Rajaeifar, M.A., Akram, A., Ghobadian, B., Rafiee, S., Heijungs, R., Tabatabaei, M., 2016. Environmental impact assessment of olive pomace oil biodiesel production and consumption: A comparative life cycle assessment. Energy 106, 87-102.

[49] Reinhard, J., Zah, R., 2011. Consequential life cycle assessment of the environmental impacts of an increased rapemethylester (RME) production in Switzerland. Biomass Bioenergy 35, 2361-2373.

[50] Rendón Hernández, F.J., Gutiérrez-Díaz, J.L., Silva Martínez, S., Hernández, J., Álvarez-Gallegos, A., 2015. Castor biodiesel-diesel blend to power a diesel engine: evaluation of the bus efficiency and emissions under driving conditions. Interciencia, 40 (1), 32-36.

[51] Energy efficiency report, Argentina..A.C., 2016.

[52] Röllin, H., 2017. Evidence for health effects of early life exposure to indoor air pollutants: what we know and what can be done. Clean Air J. 27, 2-3.

[53] Schmidt, J., 2007. Life cycle assessment of rapeseed oil and palm oil. thesis, Part 3: Life cycle inventory of rapeseed oil and palm oil. Department of Development and Planning, Aalborg University, Aalborg.

[54] Schmidt, J.H., Weidema, B.P., 2008. Shift in the marginal supply of vegetable oil. Int. J. Life Cycle Assess. 13, 235.
[55] Serrano, J., Arnau, F., Dolz, V., Tiseira, A., Lejeune, M., Auffret, N. 2008. Analysis of the capabilities of a two-stage turbocharging system to fulfil the US2007 anti-pollution directive for heavy duty diesel engines. J. Automot. Technol. 9, 277-288.

[56] Sheehan, J., Camobreco, V., Duffield, J., Graboski, M., Shapouri, H. 1998. Life cycle inventory of biodiesel and petroleum diesel for use in an urban bus. Final report. National Renewable Energy Lab. Golden, CO (US).

[57] Tavanir, 2016. 49 years electricty generation industry: statistics (in persian). Ministry of Energy, Tavanir organization, Tehran.

[58] TehranMunicipality, 2017. Introducing Tehran

[59] Thangaraja, J., Anand, K., Mehta, P.S., 2016. Biodiesel NO x penalty and control measures-a review. Renew. Sust. Energy Rev. 61, 1-24.

[60] Tica, S., Filipović, S., Živanović, P., Milovanović, B., 2010. Test run of biodiesel in public transport system in Belgrade. Energy policy 38 7014-7020.

[61] Tu, Q., Zhu, C., McAvoy, D.C., 2015. Converting campus waste into renewable energy-A case study for the University of Cincinnati. Waste Manage. 39, 258-265.

[62] Van Gerpen, J., 2005. Biodiesel processing and production. Fue Process. Technol. 86, 1097-1107.

[63] Wiloso, E.I., Heijungs, R., 2013. Key issues in conducting life cycle assessment of bio-based renewable energy sources. Life Cycle Assessment of Renewable Energy Sources. Springer, pp. 13-36.

[64] Xue, J., Grift, T.E., Hansen, A.C., 2011. Effect of biodiesel on engine performances and emissions. Renew. Sust. Energy Rev. 15, 10981116.

[65] Xue, X., Collinge, W.O., Shrake, S.O., Bilec, M.M., Landis, A.E., 2012. Regional life cycle assessment of soybean derived biodiesel for transportation fleets. Energy policy 48, 295-303.

[66] Yee, K.F., Tan, K.T., Abdullah, A.Z., Lee, K.T., 2009. Life cycle assessment of palm biodiesel: revealing facts and benefits for sustainability. Appl. Energy 86, S189-S196. 